\title{
Brachiopods, sipunculans, enteropneusts and metals from two estuarine tidal flats, Pacific, Costa Rica
}

\author{
José A. Vargas ${ }^{1,2}$, Jenaro Acuña-González ${ }^{1,3,4}$, Fiorella Vásquez ${ }^{2}$ \& Jeffrey A. Sibaja-Cordero ${ }^{1,2}$ \\ 1. Centro de Investigación en Ciencias del Mar y Limnología (CIMAR), Universidad de Costa Rica, 11501-2060, San \\ José, Costa Rica; jose.vargas@ucr.ac.cr, jeffrey.sibaja@ucr.ac.cr \\ 2. Escuela de Biología, Universidad de Costa Rica, 11501-2060, San José, Costa Rica; f.vasquezfallas@gmail.com \\ 3. Centro de Investigación en Contaminación Ambiental (CICA), Universidad de Costa Rica, 11501-2060, San José, \\ Costa Rica; jenaro.acuna@ucr.ac.cr \\ 4. Escuela de Química, Universidad de Costa Rica, 11501-2060, San José, Costa Rica
}

$$
\text { Received 15-II-2016. Corrected 16-V-2016. Accepted 31-V-2016. }
$$

\begin{abstract}
Reports on the abundances and on metal concentrations in intertidal estuarine invertebrates from the Eastern Tropical Pacific are rare. Thus, the objectives of this report are to make accessible data on the abundances (1984-1987, 49 dates; 2013, 12 dates) of sipunculans, brachiopods and hemichordates from a sand-mud flat; and on trace metals $(1996,2000)$ and abundances $(2015,3$ dates) of sipunculans and brachiopods at a sand flat in the Gulf of Nicoya estuary $\left(10^{\circ} \mathrm{N}-85^{\circ} \mathrm{W}\right)$. Cores $\left(17.7 \mathrm{~cm}^{2}\right)$ were collected at the sand-mud flat, and quadrats $\left(0.2 \mathrm{~m}^{2}\right)$ at the sand flat. The flats contrasted in their sand $(65 \%$ vs $90 \%)$ and silt+clay $(31.5 \%$ vs $5.6 \%)$ contents. At the sand-mud flat (1984-87: $1.83 \mathrm{~m}^{2}$ ) the sipunculans were represented by 13 individuals, the brachiopods by 129 and the acorn worms by 185 , with estimated maximum densities of: $5.7,29$, and $40 \mathrm{ind} . / \mathrm{m}^{2}$, respectively. Trace metal (Fe, Mn, Ni, Cr, Cd, Zn, and $\mathrm{Pb}$ ) analysis (Atomic Absorption Spectrometry) were conducted in specimens of Sipunculus nudus (Sipuncula) and Glottidia audebarti (Brachiopoda). Maximum mean concentrations in S. nudus were: For non-depurated worms, Fe $(16.0 \mathrm{mg} / \mathrm{g} \mathrm{dw})>\mathrm{Mn}(165 \mu \mathrm{g} / \mathrm{g} \mathrm{dw})>\mathrm{Zn}(81 \mu \mathrm{g} / \mathrm{g} \mathrm{dw})>\mathrm{Cu}(26 \mu \mathrm{g} / \mathrm{g} \mathrm{dw})$ $>\mathrm{Cr}(11 \mu \mathrm{g} / \mathrm{g} \mathrm{dw})>\mathrm{Ni}(10.4 \mu \mathrm{g} / \mathrm{g} \mathrm{dw})>\mathrm{Pb}(9.3 \mu \mathrm{g} / \mathrm{g} \mathrm{dw})>\mathrm{Cd}(1.2 \mu \mathrm{g} / \mathrm{g} \mathrm{dw})$. For 72 hour depurated worms: $\mathrm{Fe}(5.0 \mathrm{mg} / \mathrm{g} \mathrm{dw})>\mathrm{Mn}(61 \mu \mathrm{g} / \mathrm{g} \mathrm{dw})>\mathrm{Zn}(39 \mu \mathrm{g} / \mathrm{g} \mathrm{dw})>\mathrm{Cu}(24 \mu \mathrm{g} / \mathrm{g} \mathrm{dw})>\mathrm{Ni}(8.4 \mu \mathrm{g} / \mathrm{g} \mathrm{dw})>\mathrm{Pb}(2.7 \mu \mathrm{g} / \mathrm{g}$ $\mathrm{dw})>\mathrm{Cd}(0.62 \mu \mathrm{g} / \mathrm{g} \mathrm{dw})$. For G. audebarti: Fe $(1.6 \mathrm{mg} / \mathrm{g} \mathrm{dw}$-soft parts $)>\mathrm{Zn}(123.5 \mu \mathrm{g} / \mathrm{g} \mathrm{dw}$-soft parts $)>\mathrm{Cu}$ $(31.4 \mu \mathrm{g} / \mathrm{g} \mathrm{dw}$-pedicles $)>\mathrm{Pb}(21.0 \mu \mathrm{g} / \mathrm{g} \mathrm{dw}$-shells $)>\mathrm{Cd}(5.2 \mu \mathrm{g} / \mathrm{g} \mathrm{dw}$-soft parts $)>\mathrm{Cr}(4.7 \mu \mathrm{g} / \mathrm{g} \mathrm{dw}$-shells $)$. For sediments; Fe $(46 \mathrm{mg} / \mathrm{g} \mathrm{dw})>\mathrm{Mn}(41.3 \mu \mathrm{g} / \mathrm{g} \mathrm{dw})>\mathrm{Zn}(63 \mu \mathrm{g} / \mathrm{g} \mathrm{dw})>\mathrm{Cu}(36.2 \mu \mathrm{g} / \mathrm{g} \mathrm{dw})>\mathrm{Cr}(31.5 \mu \mathrm{g} / \mathrm{g} \mathrm{dw})$ $>\mathrm{Pb}(21.1 \mu \mathrm{g} / \mathrm{g} \mathrm{dw})>\mathrm{Ni}(16.1 \mu \mathrm{g} / \mathrm{g} \mathrm{dw})>\mathrm{Cd}(1.1 \mu \mathrm{g} / \mathrm{g} \mathrm{dw})$. These concentrations were expected for a nonindustrialized estuary. At the sand flat (Area sampled: $10.6 \mathrm{~m}^{2}$ ) 76 individuals of G. audebarti, 112 of G. albida, and 366 of $S$. nudus were collected in 2015, with estimated maximum densities of: 7.1, 10.5, and 31 ind. $/ \mathrm{m}^{2}$, respectively. Densities of $G$. audebarti and G. albida were relatively low, while those of $S$. nudus were relatively high when compared with other reports. The shell lenght of G. audebarti ranged from $9.0 \mathrm{~mm}$ to $38.0 \mathrm{~mm}$ and from $6.0 \mathrm{~mm}$ to $29.0 \mathrm{~mm}$ for G. albida. These ranges were within those found for these lingulides elsewhere. The mean length of $S$. nudus was $41 \mathrm{~mm}$ and the maximum weight was $1.6 \mathrm{~g}$, which are small. No brachiopods were found at the sand-mud flat in 2013, nor enteropneusts at the sand flat in 2015. G. audebarti had a relatively stable presence, while G. albida almost vanished from the samples at the end of 2015. The spatial distributions of the three invertebrates were found aggregated at both intertidal flats. Strong ENSO warming events during 1983 and 2015, and red tides in 1985 may have influenced the abundances. Rev. Biol. Trop. 64 (3): 1311-1331. Epub 2016 September 01.
\end{abstract}

Key words: Glottidia, Sipunculus, Apionsoma, acorn worms, tropical benthos, infauna, pollution, depuration.

From 1979 to 1983 benthic surveys were performed in the Gulf of Nicoya estuary, Pacific coast of Costa Rica, to evaluate its biodiversity and conservation status (Vargas 1995, 2016). These surveys were followed by a three-year study (1984-1987) of the community of macro-invertebrates from the Punta Morales intertidal sand-mud flat in the upper estuary (Vargas, 1987, 1988, 1989, 1996). Other publications followed focusing on the abundances 
of the main taxonomic groups, like cephalochordates (Vargas \& Dean, 2010), echinoderms (Vargas \& Solano, 2011), mollusks (VargasZamora \& Sibaja-Cordero, 2011), crustaceans (Vargas-Zamora, Sibaja-Cordero, \& Vargas-Castillo, 2012), and polychaetes (Vargas-Zamora, Sibaja-Cordero, Dean, \& Solano-Ulate, 2015).

Vargas $(1987,1988)$ also listed the presence of peanut worms (Sipuncula), Glottidia audebarti (Broderip, 1835) lamp shells (Brachiopoda) and acorn worms (Enteropneusta). Emig and Vargas (1990) reported the presence of both G. audebarti and G. albida (Hinds, 1844) in tidal flats from the Gulf of Nicoya. Comparative studies on G. audebarti by Lecuyer, Grandjean and Emig (1996) and by Kowalewski, Dyreson, Marcot, Vargas, Flessa, and Hallman (1997) included specimens from the Gulf of Nicoya. The peanut worms were identified by Cutler, Cutler and Vargas (1992) as Sipunculus nudus Linnaeus, 1766 and Apionsoma trichocephalus Sluiter, 1902. Recent reviews of the species of brachiopods and sipunculans reported from Costa Rica were conducted by Emig (2009) and Vargas and Dean (2009), respectively. The acorn worms remain as yet unidentified.

At the nearby Cocorocas sand flat, a preliminary evaluation of the presence of metals in $S$. nudus and G. audebarti was presented by Vargas and Abdullah (1997) and the final results are included herein. A comparison of the Cocorocas macrofauna with that of similar flats in other latitudes was made by Dittmann and Vargas (2001) and by Dittmann (2002). At Cocorocas the two species of brachiopods and S. nudus coexist and are important components of the macrofauna.

As a follow up of these surveys, an assessment of pollutants in sediments and invertebrates was started in 2000 at four coastal embayments of Costa Rica, including the Gulf of Nicoya. Concentrations of petroleum hydrocarbons in sea water, and trace metals and Poly-Chlorinated-Byphenyls (PCBs) in sediments were reported by Acuña-González, Vargas-Zamora, Gómez-Ramírez and García-Céspedes (2004), García-Céspedes, Acuña-González and VargasZamora(2004)andSpongberg(2004),respectively.
In addition, coliform bacteria and beach litter were studied by García, Acuña-González, Vargas-Zamora and García-Céspedes (2006).

The presence of imposex in Acanthais brevidentata snails from the Gulf was informed by Gravel, Johanning, McLachlan, Vargas, and Oberdörster (2006) and concentrations of PCBs in $S$. nudus and other sipunculans were reported by Spongberg (2006). The abundance and spatial distribution of the giant onuphid polychaete worm Americonuphis reesei in sand flats from the upper Gulf of Nicoya was described by Rojas and Vargas (2008). The presence of Pharmaceuticals and Personal Care Products (PCCP) in rivers draining into the Gulf of Nicoya and other coastal areas was evaluated by Spongberg et al. (2011). More recently, Vargas, Acuña-González, Gómez and Molina (2015) summarized data on trace metals from snails and clams collected at the four coastal sites, including the razor clam Tagelus affinis from the Cocorocas sand flat.

No recent published data is available on the abundances of brachiopods and sipunculans from the Gulf of Nicoya estuary. Reports are also rare on the abundances of these groups and acorn worms for the Eastern Tropical Pacific region. Data on trace metals in sipunculans and brachiopods are scarce worldwide. Therefore, concentrations of trace metals in $S$. nudus and $G$. audebarti from the 2000 survey are also included herein. This information may be crucial in studies assessing the potential recovery of a disturbed system like the Gulf of Nicoya estuary (Vargas, 2016). This assessment needs information on the structure (diversity and abundance) and function (energy flow) of its benthic fauna, and the presence-absence of certain groups of invertebrates may be key diagnostic factors as the review by Borja, Dauer and Elliott (2010) indicates.

Thus, the objectives of this study were to make accessible data on the abundances of sipunculans, brachiopods and hemichordates (1984-1987, 2013) at a sand-mud flat; and on trace metals $(1996,2000)$ and abundances (2015) of sipunculans and brachiopods at a sand flat in the upper Gulf of Nicoya estuary. 


\section{MATERIAL AND METHODS}

Collection sites: Samples were collected at two intertidal sedimentary environments located on the Southern shore of the Punta Morales Peninsula, upper Gulf of Nicoya estuary $\left(10^{\circ} \mathrm{N}-85^{\circ} \mathrm{W}\right)$, Pacific coast of Costa Rica (Fig. 1A) during 1984-1987 and 2013 (Punta Morales sand-mud flat) and 1996, 2000, and 2015 (Cocorocas sand flat).

The Punta Morales flat is characterized by soft sediments. A person walking on them quickly sinks to knee high (Fig. 1B). According to Vargas $(1987,1988,1996)$ conspicuous biogenic structures are tubes of the onuphid polychaetes Diopatra ornata and Americonuphis reesei (Fig. 1B) and fecal mounds of hemichordates. Snails like the scavenger Nassarius luteostoma and the predator Natica unifasciata crawl on the sediment surface year around, while the sand dollar Encope stokessi is more frequent during the dry seasons. At low tide the sediments remain wet (Fig. 1B) and small tide pools serve as refuge for crabs, shrimps, and gobiid fishes. Several species of shore birds feed at low tide on this fauna.

The Cocorocas sand flat is characterized by dark-gray sandy sediments allowing a person to walk and stand on them without sinking (Fig. 1C). The flat is under the influence of freshwater discharges from the nearby Lagarto River that carries heavy loads of sediments during the rainy season, and coarse sediments are deposited on the flat. Ripple marks are observed at low tide as well as occasional ray feeding pits. Tubes of onuphid worms are scarce and are mainly of $D$. ornata. Hemichordate fecal mounds are absent. Snails and sand dollars are also rare on the sediment surface. At low tide, the sediment surface gets almost dry (Fig. 1C) and ray feeding pits act as refuges for small fish and crustaceans. Shore birds were rarely seen on this flat. At both the Punta Morales and Cocorocas flats the infauna includes the brittle star Ophiopholis geminata. At Punta Morales the small razor clam Tagelus bourgeoisae is frequent, while at Cocorocas the larger
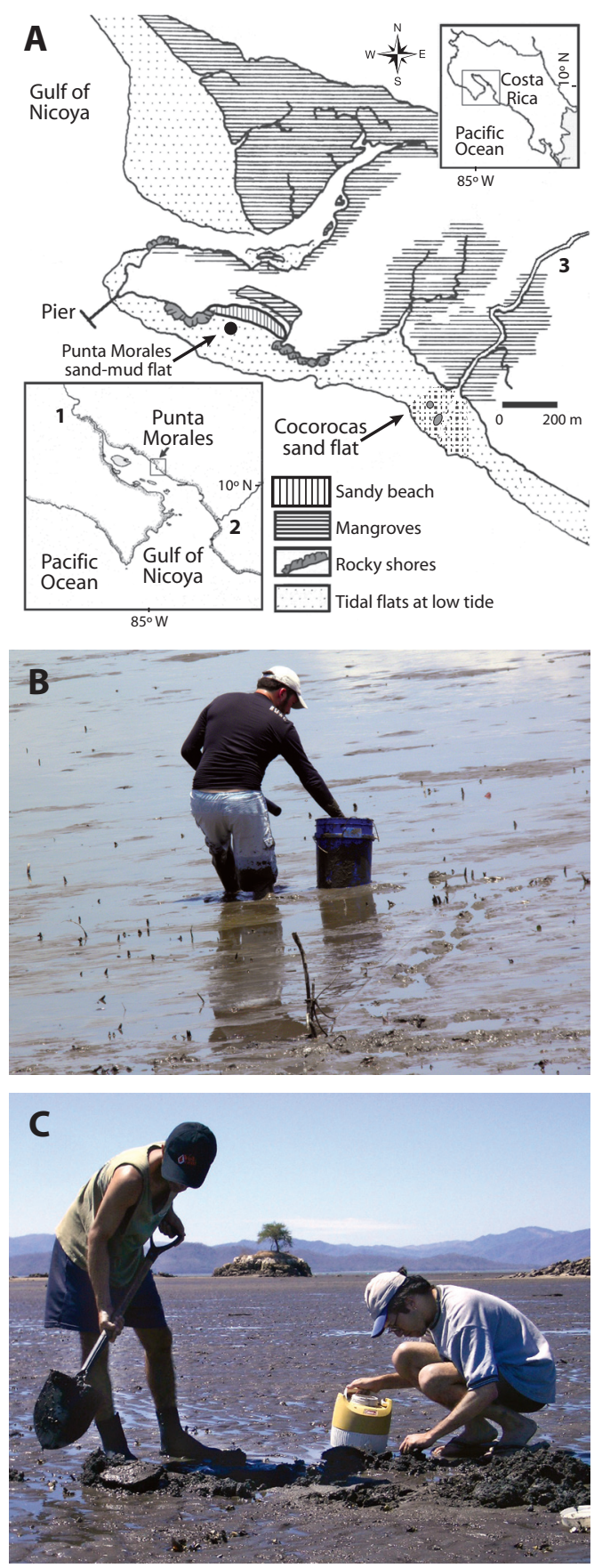

Fig. 1. A. Location of the Punta Morales and Cocorocas intertidal flats. Punta Morales Peninsula, mid upper Gulf of Nicoya estuary. Pacific, Costa Rica. $\left(10^{\circ} \mathrm{N}-85^{\circ} \mathrm{W}\right)$. 1. Tempisque River, 2. Tárcoles River, 3. Lagarto River. B. Sand mud flat. C. Sand flat. Two islets (outlined in A) are visible in the background. Note horizontal dark band marking high tide level on the tree islet. 
T. affinis is found and harvested occasionally for local consumption.

In this upper region of the Gulf (Fig. 1A) the average tidal range is $2.3 \mathrm{~m}$ and tides are semi-diurnal. The estuary is under the influence of seasonal rainfall: A rainy season occurs from May to November, followed by a dry season from December to April. In the upper estuary surface water salinity varies accordingly from about 24 psu (practical salinity units) during the rainy season, to near 34 psu during the dry season (Voorhis, Epifanio, Maurer, Dittel, \& Vargas, 1983). Primary productivity data from the Gulf of Nicoya indicates that this estuary may have reached the hypertrophic condition (Cloern, Foster, \& Kleckner, 2014). Runoff reaches the Gulf by several rivers of which the Tempisque River at the head and the Tárcoles River near the mouth (Fig. 1A) are the more important. Surface water temperatures are near $30^{\circ} \mathrm{C}$ year around, while at low tide the exposed sediments may reach temperatures near $40^{\circ} \mathrm{C}$, particularly during the sunny dry season. A strong El Niño Southern Oscillation (ENSO) event influenced the Gulf of Nicoya region during 1982-1983, as well as during 2015. In 2015 the onset of the rainy season was delayed several months and rains ended in early November due to ENSO.

\section{Sediment and specimen collections at the} Punta Morales sand-mud flat (1984-1987, 2013): The intertidal sampling protocols used at the Punta Morales flat are outlined in Vargas (1987, 1988). In summary, two sets of 14 cores (17.7 $\mathrm{cm}^{2}-15 \mathrm{~cm}$ deep) were collected at semimonthly intervals (February, 1984 to February, 1985 ) and one set of 14 cores at near monthly intervals (March, 1985 - April, 1987; and January - December, 2013) from muddy sands during low tide and within a $400 \mathrm{~m}^{2}$ plot $20 \mathrm{~m}$ apart from a sandy beach (Fig. 1A). Data from Vargas (1989) was expanded with unpublished information from March and April of 1987, for a total of 49 sampling dates. Core samples were fixed in Rose Bengal stained formalin in sea water. Preserved cores were sieved thru a 500 micron mesh. Sorted specimens of brachiopods (Glottidia spp.), sipunculans (S. nudus,
A. trichocephalus), and acorn worms (Fig. 2A) were kept in vials filled with $70 \%$ ethanol. Sediment cores were also collected for determinations of grain size (sieve analysis according to Gray \& Elliot, 2010) and organic matter content (by combustion at $450{ }^{\circ} \mathrm{C}$ ), dried at $65{ }^{\circ} \mathrm{C}$, and kept in sealed polyester bags until analysis.

Specimen collection at Cocoracas sand flat (1996, 2000, 2015): On June 10, 1996 individuals of $S$. nudus (Fig. 2B, Fig. 2C, Fig. 2D) and of the brachiopod G. audebarti (Fig. 2F) were collected at the Cocorocas flat along a $100 \mathrm{~m}$ long transect perpendicular to the shore and running between two islets (Fig. 1A, Fig. 1C). Sediment clumps were removed with a shovel to a depth of $20 \mathrm{~cm}$, broken up by hand, and brachiopods and sipunculans placed in acid-washed polyester bags. At the laboratory the specimens were vacuum dryed for international shipment. A total of 40 individuals of $S$. nudus, and 20 of G. audebarti were selected to perform trace metal analyses by means of Atomic Absorption Spectrometry (AAS). Analyses were accomplished by M. Abdullah at the Department of Biology of the University of Oslo (Norway) on non-depurated whole $S$. nudus, and in tissues, pedicles, and shells of $G$. audearti.

On March 8th, 2000, sediment clumps were again removed with a shovel to a depth of $20 \mathrm{~cm}$. A total of 100 specimens of $S$. nudus were collected at Cocorocas and transported to the laboratory in a cooler filled with sea water from the site. At the laboratory the worms were kept in cooled $\left(20^{\circ} \mathrm{C}\right)$ sea water for two hours, rinsed with filtered sea water, blotted dry on a paper towel, measured, weighed, and separated into two groups of 50 individuals each. One group was placed in a heat-sealable, acid-washed polyester bag and stored frozen $\left(-18^{\circ} \mathrm{C}\right)$ until analysis. The second group was kept in a plastic container filled with filtered sea water from the site and aerated with portable plastic aquarium pumps to allow the worms to remove sediments and other matter from their digestive tracts (Fig. 2 D). Sea water, feces, and dead organisms were discarded every 12 hours 

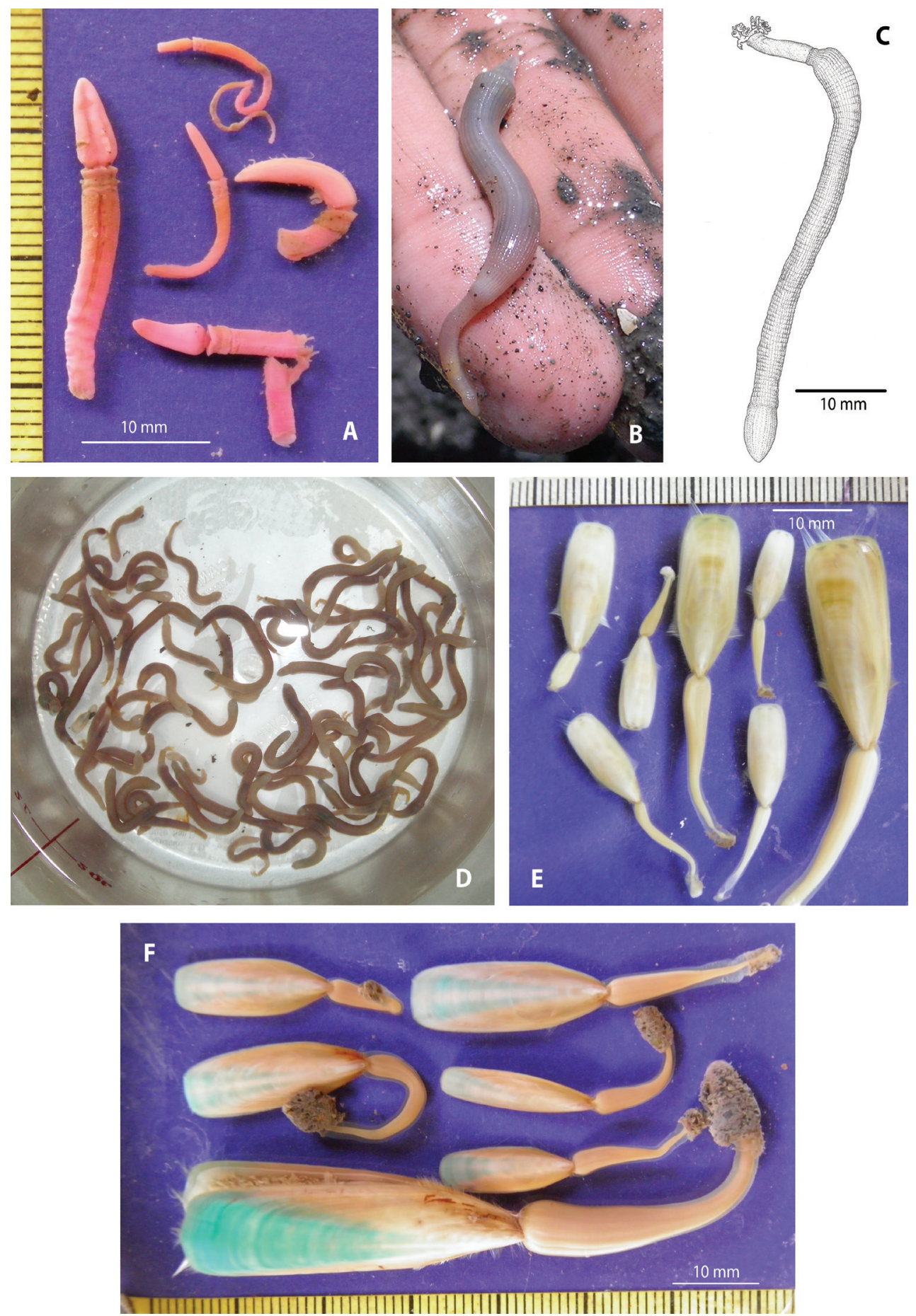

Fig. 2. A. Anterior regions (proboscis, collar, and part of trunk) of five Rose Bengal stained acorn worms. B. Live Sipunculus nudus collected at the sand flat. C. S. nudus drawn from live specimen. D. S. nudus during the $72 \mathrm{~h}$ depuration process. E. G. albida. Note setae bundles. F. Rose Bengal stained Glottidia audebarti. Note tips of pedicles with agglomerated sand grains. 
and the container filled with fresh filtered sea water. The procedure was repeated six times for a total of 72 hours. Forty-two individuals were alive (able to move) at the end of the depuration period. The depurated worms were removed by hand, blotted dry on a paper towel, measured, weighed, and stored frozen $\left(-18{ }^{\circ} \mathrm{C}\right)$ as above until analysis. Trace metal analyses were made at the Research Centre on Marine Pollution (CICA) of the University of Costa Rica. Metal determinations (Fe, Mn, Ni, Zn, $\mathrm{Pb}, \mathrm{Cd}$ ) were performed following methods described by Vargas, Acuña-González, Gómez, and Molina (2015). In summary: Certified reference materials and blank tests were run. $\mathrm{Fe}, \mathrm{Mn}$ and $\mathrm{Zn}$ were analyzed by Flame AAS (Perkin Elmer ${ }^{\circledR}$ 3300). Cd, Ni and $\mathrm{Pb}$ were analyzed by Graphite Furnace AAS (Perkin Elmer $^{\circledR}$ HGA 600). The results for iron are expressed as $\mathrm{mg} / \mathrm{g}$ dry weight $(\mathrm{mg} / \mathrm{g} \mathrm{dw}$ ), and all other concentrations are expressed in parts per million / dry weight $(\mu \mathrm{g} / \mathrm{g} \mathrm{dw})$. Sediment samples for trace metal analysis were collected using an acid-washed plastic corer, placed in heat-sealable, acid-washed polyester bags, and stored frozen $\left(-18^{\circ} \mathrm{C}\right)$ until analysis.

On July 6, October 2, and December 15,2015 , peanut worms (S. nudus) and brachiopods (G. audebarti and G. albida) were collected at the Cocorocas sand flat to verify its presence and estimate their relative abundances. A wooden frame $(50 \times 40 \mathrm{~cm})$ was pressed on the sediment surface to mark the sampling area $\left(0.20 \mathrm{~m}^{2}\right)$. A minimum of $15(3.0$ $\left.\mathrm{m}^{2}\right)$ and a maximum of $20\left(4.0 \mathrm{~m}^{2}\right)$ samples were collected during low tide, along a $200 \mathrm{~m}$ transect running between two islets (Fig. 1C) and perpendicular to the shoreline. Each sample was collected $10 \mathrm{~m}$ apart from each other. Sampling was scheduled to coincide with very low tides near noon time. Sediment clumps were removed with a shovel to a depth of 20 $\mathrm{cm}$, broken up by hand, and brachiopods and sipunculans placed in plastic bags with sea water from nearby tide pools. Brachiopod specimens from each quadrat were split in two groups: those with cream-white shells (G. albida, Fig. 2E) and those with dark-green coloration on the anterior region ( $G$. audebarti, Fig. 2F). Brachiopods were blotted dry on paper towel and shell length (center of shell tip to pedicle attachment) measured to the nearest $0.5 \mathrm{~mm}$. Final preservation of organisms was in $70 \%$ ethanol. Specimens of $S$. nudus were also preserved in $70 \%$ ethanol for 24 hours and quickly blotted dry on a paper towel and weighed. Samples for grain size analysis and organic matter content were collected by hand from sediment removed by the shovel, dried at $65{ }^{\circ} \mathrm{C}$, and kept in sealed polyester bags as described before.

\section{RESULTS}

Sediment compositions: The sediment compositions of the Punta Morales (1984, 2013) sand-mud flat and of the Cocorocas sand flat (2015) are included in Table 1. The sand-mud flat was characterized in 1984 by $65.5 \%$ sand $(46.4 \%$ fine sand, $15.1 \%$ very fine sand), the silt+clay content was $31.5 \%$

TABLE 1

Mean percentages of dry sediment fractions retained on sieves. Lower size (microns) limit of particles: Granules (2000), coarse+very coarse sands (1000), medium sand (500), fine sand (250), very fine sand (63). Silt+clay: fraction washed thru a 63 micron mesh sieve. Percent organic matter content (by combustion at $450^{\circ} \mathrm{C}$ ). A. Punta Morales sand-mud flat (1984, n=10). B. Punta Morales sand-mud flat (2013, $n=12)$. C. Cocorocas sand flat $(2015, n=3)$. Gulf of Nicoya estuary, Pacific coast of Costa Rica

\begin{tabular}{lccccccccc} 
& Granules & Coarse+Very coarse & Medium & Fine & Very fine & Silt+clay & Total & Organics \\
A. & 0.7 & 0.8 & 3.3 & 46.4 & 15.1 & 31.5 & 97.8 & 2.0 \\
B. & 0.8 & 1.1 & 1.8 & 5.6 & 33.0 & 57.6 & 99.9 & 8.0 \\
& & & & & & & & & \\
C. & 3.7 & 10.7 & 9.1 & 29.2 & 41.7 & 5.6 & 100 & 3.0 \\
\hline
\end{tabular}


and organic matter was $2 \%$. A change towards finer sediments and organic enrichment was found during the 2013 survey: $41.3 \%$ sand (5.6 fine sand, $33.0 \%$ very fine sand), the silt + clay content was $57.6 \%$ and organic matter was $8 \%$. Coarse + very course sands were around $1 \%$ in both surveys (Table $1 \mathrm{~A}, \mathrm{~B}$ ). The Cocorocas sand flat samples contained higher percentages of sand $(90.7 \%)$ of which $29.2 \%$ was fine sand. Coarse + very coarse sands were $10.7 \%$. The silt+clay content was only $5.6 \%$ and organic matter was around $3 \%$ (Table $1 \mathrm{C}$ ).

The 1984-1987 survey: Examples of the acorn worms and brachiopods collected are included in Fig. 2A, Fig. 2F. Organisms of the three groups had many on a size range that may represent juvenile forms. Acorn worms in particular included many organisms around $10 \mathrm{~mm}$ in length (Fig. 2A). The total numbers were: 13 sipunculans (12 ind. of $S$. nudus, 1 ind. of A. trichocephalus) 129 brachiopods and 185 hemichordates (Fig. 3). The total area sampled was $1.83 \mathrm{~m}^{2}$.

The abundances of these three groups at the Punta Morales sand-mud flat for the 49 dates of the 1984-1987 survey are included in Fig. 3. Sampling started in February 1984, shortly after the impact of the severe 19821983 ENSO high temperatures and dry conditions had returned to near normal values in the Central American region. Red tides were frequent in the upper Gulf of Nicoya in 1985, particularly after June (Fig. 3). The periods from the start of sampling to about June 1984, and from around May 1985 to October 1985 were characterized by low to zero abundances. In spite of the fact that after March 1985 the sampling effort was smaller in space (14 cores) and in time (monthly), abundances were higher during the rainy seasons. Abundance patterns of brachiopods and acorn worms in particular were similar since both groups were absent early on 1984, begun to increase and reached high numbers around the mid rainy season of 1984, became scarcer during 1985 and early 1986, and increased slightly during the dry season of 1986-1987. The presence of a few sipunculans was restricted to the rainy seasons of 1984 and 1985 (Fig. 3).

Metal concentrations (1996, 2000): Examples of the peanut worm Sipunculus nudus are included in Fig. 2B, Fig. 2C, Fig. 2D. The concentrations of trace metals in non-depurated S. nudus, soft parts, pedicles, and shells of Glottidia audebarti, and sediments collected in 1996 are included in Table 2. S. nudus had higher mean concentrations of $\mathrm{Fe}$ and $\mathrm{Cr}$ than G. audebarti, while the brachiopod presented higher mean concentrations of $\mathrm{Zn}$ and $\mathrm{Cd}$ (soft parts), $\mathrm{Pb}$ (shells) and $\mathrm{Cu}$ (pedicles). $\mathrm{Pb}$ concentrations were similar in organisms and in sediments, while those of $\mathrm{Zn}$ and $\mathrm{Cd}$ were higher in organisms than in sediments.

TABLE 2

Mean $(\mathrm{n}=4)$ metal concentrations ( \pm Standard Deviation) in non-depurated whole Sipunculus nudus (Sipuncula), in tissues and shells of Glottidia audebarti (Brachiopoda), and in sediments. Unpublished data from Vargas, J.A. \& M.I. Abdullah, 1997, AAS (Atomic Adsorption Spectrometry, Dept. of Biology, University of Oslo, Norway). Cocorocas intertidal sand flat. Gulf of Nicoya estuary, Pacific, Costa Rica. March, 1996. Concentrations in $\mu \mathrm{g} / \mathrm{g} \mathrm{dw}$, except for iron $(\mathrm{mg} / \mathrm{g} \mathrm{dw})$

\begin{tabular}{lcccccc}
\multicolumn{1}{c}{ Species / metal } & $\mathrm{Fe}$ & $\mathrm{Cr}$ & $\mathrm{Zn}$ & $\mathrm{Pb}$ & $\mathrm{Cu}$ & $\mathrm{Cd}$ \\
S. nudus, whole & $5.4 \pm 0.7$ & $11.0 \pm 5.0$ & $56.0 \pm 2.0$ & $9.3 \pm 0.2$ & $26.0 \pm 2.0$ & $1.2 \pm 0.5$ \\
G. audebarti, soft parts & $1.60 \pm 0.07$ & $1.5 \pm 0.1$ & $123.5 \pm 7.5$ & $2.39 \pm 0.65$ & $7.9 \pm 0.2$ & $5.20 \pm 0.15$ \\
G. audebarti, pedicles & $0.48 \pm 0.01$ & $2.1 \pm 0.1$ & $42.6 \pm 0.1$ & $2.4 \pm 0.1$ & $31.4 \pm 0.2$ & $0.37 \pm 0.02$ \\
G. audebarti, shells & $0.57 \pm 0.07$ & $4.7 \pm 0.8$ & $73.7 \pm 0.1$ & $21.0 \pm 0.6$ & $12.88 \pm 0.01$ & $3.86 \pm 0.01$ \\
Sediments & $25.8 \pm 5.3$ & $31.5 \pm 0.5$ & $62.6 \pm 0.5$ & $21.1 \pm 0.2$ & $36.2 \pm 0.2$ & $1.10 \pm 0.02$ \\
Blanks & $<0.04$ & $<0.02$ & 0.06 & $<0.05$ & $<0.02$ & $<0.01$ \\
\hline
\end{tabular}



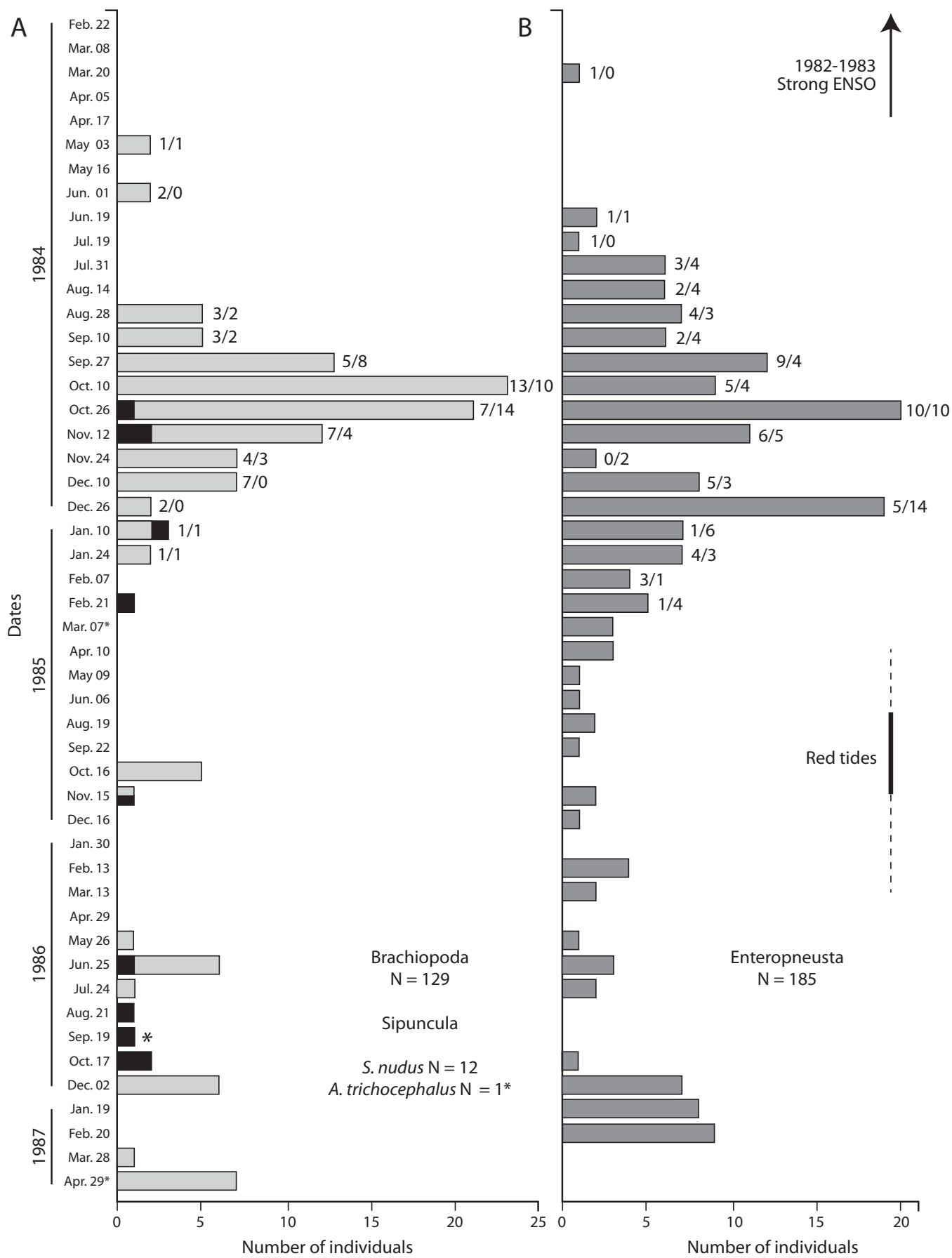

Fig. 3. Number of individuals per date (49 dates) of: A. Lingulide brachiopods (Brachiopoda, light grey bars) and peanut worms (Sipuncula, black bars). B. Acorn worms (Enteropneusta, dark gray bars) found in a $400 \mathrm{~m}^{2}$ sampling plot at the Punta Morales intertidal sand-mud flat, Gulf of Nicoya estuary, Pacific coast of Costa Rica (1984-1987). Feb. 22 , 1984 to Feb. 21, 1985: Semi-monthly sampling of two sets of 14 cores per date. Numbers of acorn worms and brachiopods found on each 14 core set are indicated on the top of the bars. Sipunculans were found on one of the sets. Mar. 07, 1985 to Apr. 29, 1987: Monthly sampling of 14 cores per date. Core area $17.7 \mathrm{~cm}^{2}$, core depth $15 \mathrm{~cm}$. Mesh screen: 500 microns. 
Mean concentrations of $\mathrm{Fe}, \mathrm{Cu}$, and $\mathrm{Cr}$ were higher in sediments.

The concentrations of metals in tissues of non-depurated and depurated whole $S$. nudus collected in 2000 are included in Table 3A. In non-depurated worms mean concentrations of Fe and Zn were higher in 2000 than in 1996, while $\mathrm{Pb}$ and $\mathrm{Cd}$ were lower in 2000; $\mathrm{Cu}$ was detected in similar concentrations for both surveys (Tables 2, 3A). When median concentrations of non-depurated and depurated $S$. nudus are compared, these decreased for all metals except Cd (Table 3A).

Maximum mean concentrations of metals in $S$. nudus worms found either during the 1996 or 2000 surveys, were: For non-depurated worms; Fe $(19.4 \mathrm{mg} / \mathrm{g} \mathrm{dw})>\mathrm{Mn}(165 \mu \mathrm{g} / \mathrm{g}$ $\mathrm{dw})>\mathrm{Zn}(81 \mu \mathrm{g} / \mathrm{g} \mathrm{dw})>\mathrm{Cu}(26 \mu \mathrm{g} / \mathrm{g} \mathrm{dw})>\mathrm{Cr}$ $(11 \mu \mathrm{g} / \mathrm{g} \mathrm{dw})>\mathrm{Ni}(10.4 \mu \mathrm{g} / \mathrm{g} \mathrm{dw})>\mathrm{Pb}(9.3 \mu \mathrm{g} / \mathrm{g}$ $\mathrm{dw})>\mathrm{Cd}(1.2 \mu \mathrm{g} / \mathrm{g} \mathrm{dw})$. For depurated worms: Fe $(6.2 \mathrm{mg} / \mathrm{g} \mathrm{dw})>\operatorname{Mn}(61 \mu \mathrm{g} / \mathrm{g} \mathrm{dw})>\mathrm{Zn}$ $(39 \mu \mathrm{g} / \mathrm{g} \mathrm{dw})>\mathrm{Cu}(24 \mu \mathrm{g} / \mathrm{g} \mathrm{dw})>\mathrm{Ni}(8.4 \mu \mathrm{g} / \mathrm{g}$ $\mathrm{dw})>\mathrm{Pb}(2.7 \mu \mathrm{g} / \mathrm{g} \mathrm{dw})>\mathrm{Cd}(0.62 \mu \mathrm{g} / \mathrm{g} \mathrm{dw})$. However, median concentrations in non-depurated $v s$ non-depurated $S$. nudus were not significant (Table 3A). For G. audebarti (1996 only): Fe $(1.6 \mathrm{mg} / \mathrm{g} \mathrm{dw}$-soft parts $)>\mathrm{Zn}(123.4 \mu \mathrm{g} / \mathrm{g}$ dw-soft parts) $>\mathrm{Cu}(31.4 \mu \mathrm{g} / \mathrm{g} \mathrm{dw}$-pedicles $)$ $>\mathrm{Pb}(21.0 \mu \mathrm{g} / \mathrm{g} \mathrm{dw}$-shells $)>\mathrm{Cd}(5.2 \mu \mathrm{g} / \mathrm{g}$ dw-soft parts $)>\mathrm{Cr}(4.7 \mu \mathrm{g} / \mathrm{g} \mathrm{dw}$-shells $)$. For sediments: Fe $(46 \mathrm{mg} / \mathrm{g} \mathrm{dw})>\mathrm{Mn}(41.3 \mu \mathrm{g} / \mathrm{g}$ $\mathrm{dw})>\mathrm{Zn}(63 \mu \mathrm{g} / \mathrm{g} \mathrm{dw})>\mathrm{Cu}(36.2 \mu \mathrm{g} / \mathrm{g} \mathrm{dw})>$ $\mathrm{Cr}(31.5 \mu \mathrm{g} / \mathrm{g} \mathrm{dw})>\mathrm{Pb}(21.1 \mu \mathrm{g} / \mathrm{g} \mathrm{dw})>\mathrm{Ni}$ $(16.1 \mu \mathrm{g} / \mathrm{g} \mathrm{dw})>\mathrm{Cd}(1.1 \mu \mathrm{g} / \mathrm{g} \mathrm{dw})$.

The weight on non-depurated $S$. nudus ranged from $0.65 \mathrm{~g}$ to $1.67 \mathrm{~g}$, with an average of $0.95 \mathrm{~g}$, while the weight of depurated worms ranged from $0.61 \mathrm{~g}$ to $1.35 \mathrm{~g}$, with a mean of $0.84 \mathrm{~g}$. The weight of depurated S. nudus was significantly lower after the depuration period (Table 3B). There was no statistically significant difference in length of non-depurated $v s$ depurated organisms The mean length of $S$. nudus was $45 \mathrm{~mm}$, with a maximum of $65 \mathrm{~mm}$ (Table 3B, Fig. 2 B.C).

The 2013 survey of the sand-mud flat: During the 2013 monthly core sampling at the
Punta Morales sand-mud flat no specimens of brachiopods and of $S$. nudus were found. However, the Sipuncula included seven individuals of A. trichocephalus (Fig. 4). The acorn worms (Enteropneusta) were represented by 16 specimens found mainly during the rainy season (Fig. 4).

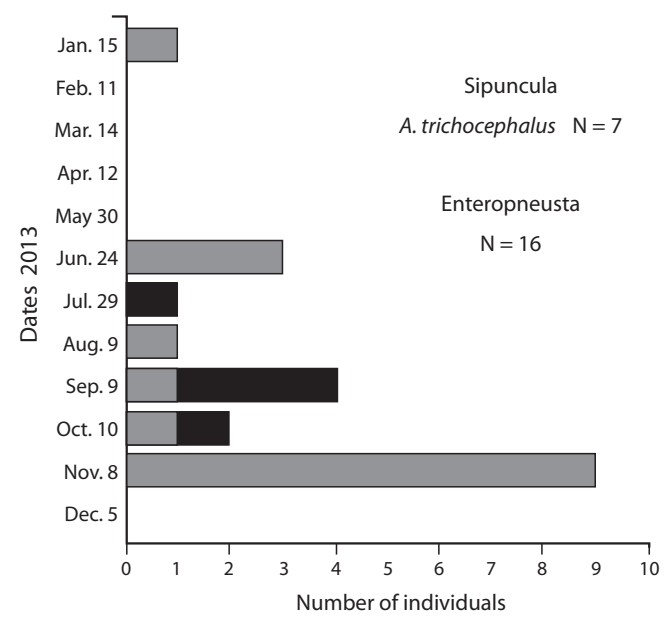

Fig. 4. Number of individuals per date (12 dates) of the sipunculan, Apionsoma trichocephalus (dark bars), and acorn worms (Enteropneusta, gray bars) found in a $400 \mathrm{~m}^{2}$ sampling plot at the Punta Morales intertidal sand-mud flat, Gulf of Nicoya estuary, Pacific coast of Costa Rica (2013).Monthly sampling of 14 cores per date (core area: $17.7 \mathrm{~cm}^{2}$, core depth: $15 \mathrm{~cm}, 500$ micron mesh screen). No brachiopods were found in the 168 core samples. (Area: $0.297 \mathrm{~m}^{2}$ )

The 2015 survey of the sand flat: Examples of the brachiopod G. albida collected are included in Fig. 2E. Samples were collected at the Cocorocas flat in July, October, and December of 2015, a year when high temperatures and dry conditions in the Eastern Pacific region were enhanced by the ENSO event (NOAA, 2016). The presence at the sand flat of brachiopods ( $G$. albida and G. audebarti) and $S$. nudus worms was confirmed during sampling conducted in 2015. These three species were found frequently living together on a single quadrat area $\left(0.2 \mathrm{~m}^{2}\right)$. Acorn worms, however, were not found.

A total of 76 individuals of G. audebarti, 112 of G. albida and 366 of $S$. nudus were 
TABLE 3

A. Metal concentrations in whole soft tissues of the deposit feeder Sipunculus nudus ( $n=$ subsamples).

B. Length of body (mm) and weigth (g) of blotted-dry live non-depurated, and after 72 hour depuration of individuals of S. nudus $(\mathrm{n}=42)$. C. Metal concentrations in sediments. D. Maximum concentrations in the razor clam Tagelus affinis from the Cocorocas sand flat (2006)*. All concentratios in $\mu \mathrm{g} / \mathrm{g} \mathrm{dw}$ except for iron (mg/g dw). Cocorocas sand flat, Gulf of Nicoya estuary, Pacific coast of Costa Rica. March 8, 2000

\begin{tabular}{|c|c|c|c|c|c|c|c|c|c|}
\hline Depurative Treatment & \multicolumn{2}{|c|}{ Statistics } & $\mathrm{Fe}$ & $\mathrm{Mn}$ & $\mathrm{Ni}$ & $\mathrm{Zn}$ & $\mathrm{Pb}$ & $\mathrm{Cu}$ & $\mathrm{Cd}$ \\
\hline \multirow{6}{*}{ No } & \multirow[t]{2}{*}{ Range } & \multirow{6}{*}{$\begin{array}{l}\text { Min. } \\
\text { Max. }\end{array}$} & 16.1 & 34.4 & 1.17 & 8.44 & 0.60 & 6.42 & 0.17 \\
\hline & & & 22.5 & 234.6 & 15.57 & 144.0 & 4.67 & 29.1 & 1.64 \\
\hline & Mean & & 16.0 & 165 & 10.4 & 81 & 2.8 & 20.7 & 0.63 \\
\hline & S.D. & & 8.2 & 113 & 8.0 & 53 & 1.5 & 9.9 & 0.61 \\
\hline & $n$ & & 5 & 3 & 3 & 5 & 5 & 4 & 5 \\
\hline & Median & & 16.9 & 226.0 & 14.5 & 76.7 & 2.95 & 23.6 & 0.53 \\
\hline \multirow{6}{*}{ Yes } & \multirow[t]{2}{*}{ Range } & Min. & 1.55 & 1.23 & 0.15 & 5.55 & 0.23 & 1.86 & 0.06 \\
\hline & & Max. & 9.21 & 105.7 & 12.75 & 61.1 & 6.39 & 52.7 & 1.00 \\
\hline & Mean & & $\mathbf{5 . 0}$ & 61 & 8.4 & 39 & 2.7 & 24 & 0.62 \\
\hline & S.D. & & 3.9 & 54 & 7.1 & 23 & 2.3 & 21 & 0.32 \\
\hline & $n$ & & 5 & 3 & 3 & 5 & 5 & 4 & 5 \\
\hline & Median & & 6.52 & 77.4 & 12.2 & 43.9 & 2.59 & 21.3 & 0.65 \\
\hline
\end{tabular}

Mann-Whitney U test for equal medians of depurated vs non-depurated $S$. nudus: $\mathrm{Fe}(\mathrm{p}=0.06), \mathrm{Mn}(\mathrm{p}=0.38), \mathrm{Ni}(\mathrm{p}=0.38)$, $\mathrm{Zn}(\mathrm{p}=0.21), \mathrm{Pb}(\mathrm{p}=0.83), \mathrm{Cu}(\mathrm{p}=0.88), \mathrm{Cd}(\mathrm{p}=0.83)$. All $\mathrm{p}=$ non-significant.

B

\begin{tabular}{lcccc} 
& \multicolumn{2}{c}{ Non depurated } & \multicolumn{2}{c}{ Depurated } \\
Mean & Length & Weight & Length & Weight \\
S.D. & 45.1 & 0.955 & 45.0 & 0.840 \\
Min & 8.28 & 0.260 & 5.02 & 0.160 \\
Max & 30.0 & 0.650 & 32.0 & 0.611 \\
Median & 65.0 & 1.670 & 60.0 & 1.352 \\
\hline
\end{tabular}

Mann-Whitney U test for equal weight medians: $571(\mathrm{p}=0.01)$ significant.

Mann-Whitney $U$ test for equal length medians: $807(\mathrm{p}=0.76)$ non significant.

C

\begin{tabular}{lcccccc}
\multicolumn{1}{r}{ Statistics } & $\mathrm{Fe}$ & $\mathrm{Mn}$ & $\mathrm{Ni}$ & $\mathrm{Zn}$ & $\mathrm{Pb}$ \\
Range & Min. & 20.9 & 203.8 & 7.14 & 30.2 & 5.45 \\
& Max. & 60.3 & 549.3 & 20.6 & 83.1 & 12.6 \\
Mean $(n=4)$ & $\mathbf{4 6}$ & $\mathbf{4 1 3}$ & $\mathbf{1 6 . 1}$ & $\mathbf{6 3}$ & $\mathbf{1 0 . 1}$ \\
S.D. & 17 & 148 & 6.1 & 23 & 3.2 & 11.1 \\
Median & 50.4 & 449.2 & 18.3 & 69.9 & \\
\hline
\end{tabular}

S.D. $=$ standard deviation. $n=$ number of samples.

D

\begin{tabular}{lcccc} 
& $\mathrm{Fe}$ & $\mathrm{Mn}$ & $\mathrm{Ni}$ & $\mathrm{Zn}$ \\
T. affinis non depurated & $2160 \pm 55$ & $255.2 \pm 3.6$ & $4.13 \pm 0.09$ & $206.7 \pm 4.1$ \\
T. affinis depurated & $290.3 \pm 6.5$ & $24.97 \pm 0.90$ & $1.60 \pm 0.06$ & $153.5 \pm 3.1$ \\
\hline
\end{tabular}

* Data from Vargas, Acuña-González, Gómez \& Molina (2015). 

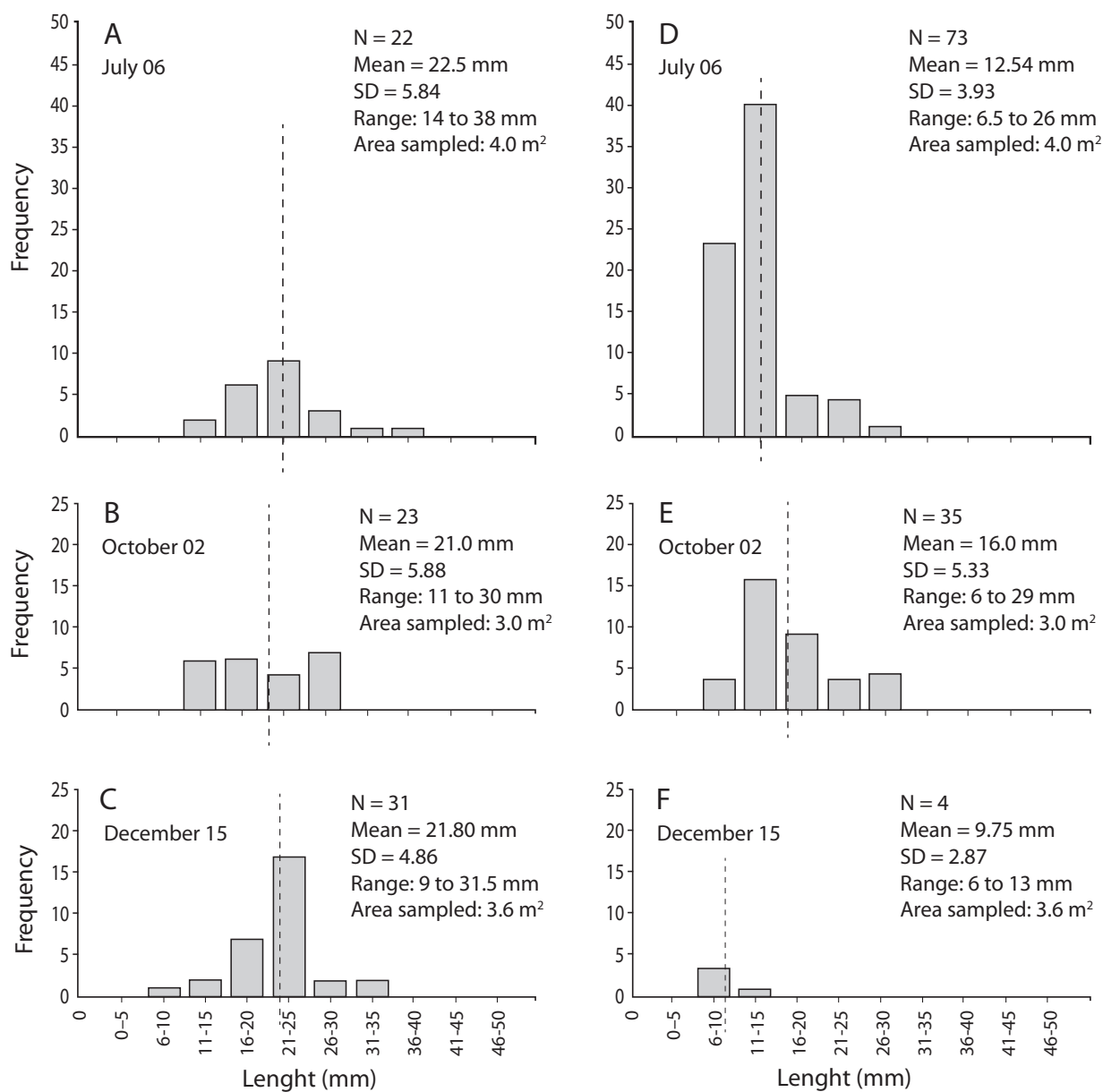

Fig. 5. Arbitrary shell length groups (mm) of brachiopods: A, B, C. Glottidia audebarti. D, E, F. G. albida. Specimens collected on July 2 (early rainy season), October 6 (mid rainy season), and December 15 (dry season) 2015. Cocorocas sand flat, Gulf of Nicoya estuary, Pacific, Costa Rica. Vertical dashed lines = mean length of individuals.

found in a pooled sample area of $10.6 \mathrm{~m}^{2}$ (Fig. 5). The size range of G. audebarti was from $9.0 \mathrm{~mm}$ to $38.0 \mathrm{~mm}$, while for G. albida the range was from $6.0 \mathrm{~mm}$ to $29.0 \mathrm{~mm}$ (Fig. 5). The weight range of $S$. nudus was from $0.10 \mathrm{~g}$ to $2.55 \mathrm{~g}$ (Fig. 6).

Abundances (22 - 23 - 31 ind.) of G. audebarti were relatively stable. The smaller and the bigger specimens were both collected in December, and mean shell lengths (22.5 - 21.0 - $21.8 \mathrm{~mm}$ ) were similar during the sampling period (Fig. 5 A, Fig. 5B, Fig. 5C). On the other hand, G. albida abundances (73 - $35-4$ ind.) declined sharply during the period. The smaller specimens of $G$. albida were found during the three sampling dates, while the bigger individuals were found in July and October, and mean shell lengths increased and then decreased (12.5 - 16.0 - $9.7 \mathrm{~mm})$, Fig. 5 D, Fig. 5E, Fig. 5F. The abundance of $S$. nudus was high towards the end of the rainy season. Individuals in the ranges below $1.0 \mathrm{~g}$ were more common along the sampling period, but the increase in numbers of those above $1.0 \mathrm{~g}$ was modest (Fig. 5 A, Fig. 5B, Fig. 5C). Two individuals of the larger (approx. $200 \mathrm{~mm}$ ) sipunculan, Xenosiphon branchiatus were also found in the Cocorocas samples. 

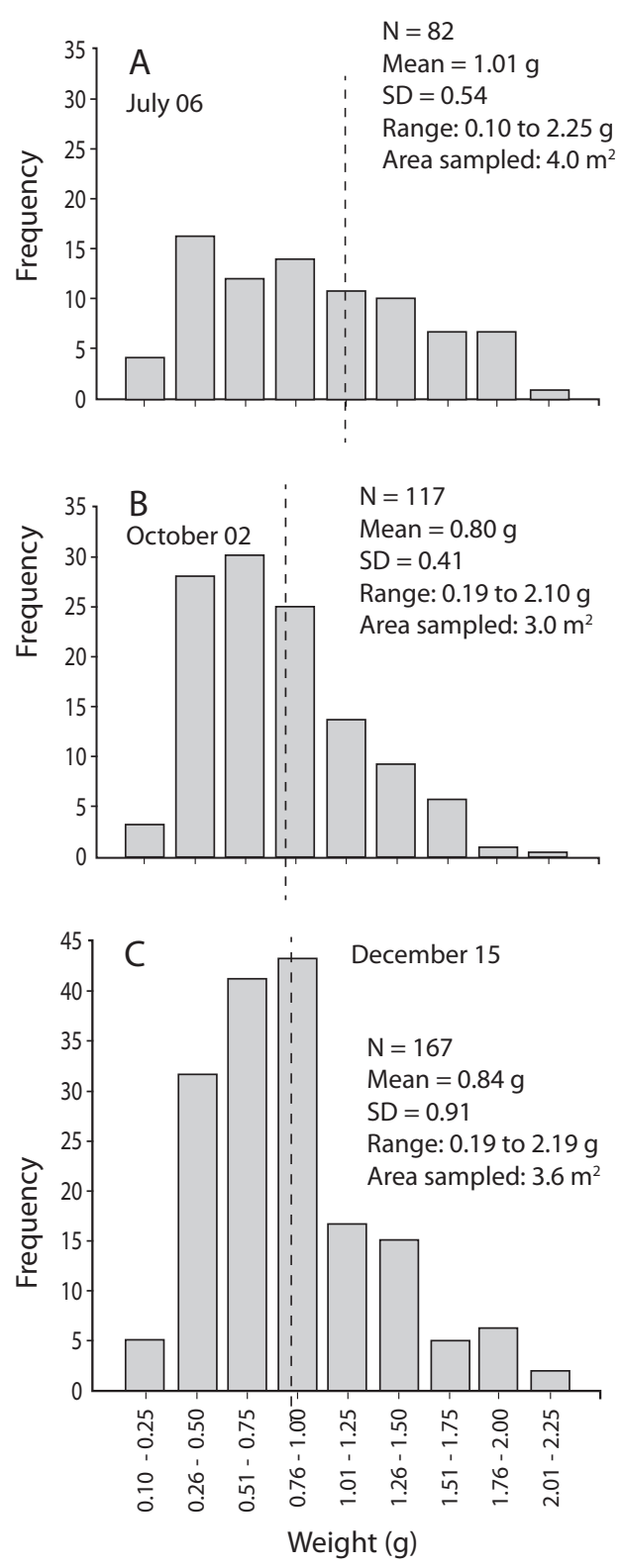

Fig. 6. Arbitrary weight (grams) groups for the ethanol preserved sipunculan Sipunculus nudus: A. July 2 (early rainy season), B. October 2 (mid rainy season), C. December 15 (dry season), 2015. Cocorocas sand flat, Gulf of Nicoya estuary, Pacific, Costa Rica. Vertical dashed line $=$ mean weight of individuals.
Spatial patterns: During the 1984-1987 survey the maximum numbers of individuals of acorn worms, brachiopods and $S$. nudus found in a core $\left(17.7 \mathrm{~cm}^{2}\right)$ were 5,3 , and 5 , respectively. Estimated mean densities of the three groups were $29,5.7$ and 40 ind. $/ \mathrm{m}^{2}$, respectively (Table 4). During the 2015 survey mean abundances (ind. $/ \mathrm{m}^{2}$ ) for the three sampling dates were 7.1 (G. audebarti), 10.5 (G. albida), and 34.5 (S. nudus), respectively. The maximum numbers of $G$. audebarti, G. albida, and $S$. nudus found in a quadrat $\left(0.2 \mathrm{~m}^{2}\right)$ were 11, 18 and 20, respectively. Estimated densities (ind. $/ \mathrm{m}^{2}$ ) for the date with the maximum number of individuals of each species were: 8.6 (G. audebarti), 18.2 (G. albida) and 46.4 (S. nudus), Table 4.

\section{DISCUSSION}

The Brachiopoda and Hemichordata are considered two separate groups each with the category of Phylum, while the Sipuncula is presently grouped by some authors within the Phylum Annelida based on molecular evidence (Brusca, Moore, \& Shuster, 2016).

The lamp shells, acorn worms and peanut worms include organisms that burrow in sediments of marine and estuarine habitats worldwide. The early information on these groups was summarized by Hyman (1959) who mentioned several examples of the scarce literature available at the time for tropical regions. More recent reviews were published by Cutler (1994), Emig (1997, 2009) Cameron (2005) and Vargas and Dean (2009). These works also indicate that for tropical intertidal flats the gap of information on diversity, distribution and abundance of these benthic organisms continues to be significant. Dittmann and Vargas (2001) and Dittmann (2002) have pointed out that among key organisms structuring the fauna of tropical tidal flats are 
TABLE 4

Distribution of organisms among sampling units for the date with the maximum number of individuals (see Figs. 3, 4, 5). Total number and date. Estimated mean density (ind. $\left./ \mathrm{m}^{2}\right)$. A. Punta Morales (Corer: $17.7 \mathrm{~cm}^{2}$ ) B. Cocorocas (Wooden frame: $2000 \mathrm{~cm}^{2}$ ). Intertidal flats, Gulf of Nicoya estuary, Pacific, Costa Rica

\begin{tabular}{|c|c|c|c|c|c|c|c|c|c|c|c|c|c|c|c|c|c|c|c|c|c|c|}
\hline \multirow[b]{2}{*}{ A. 1984-1987 } & \multicolumn{21}{|c|}{ Distribution, (total number, date), mean density $/ \mathrm{m}^{2}$} & \multirow{2}{*}{ Ind. $/ \mathrm{m}^{2}$} \\
\hline & & & & & & & & & & & & & & & & & & & & & & \\
\hline Enteropneusta & 1 & 0 & 0 & 0 & 0 & 2 & 1 & 0 & 3 & 0 & 0 & 5 & 2 & 0 & - & - & - & - & - & - & $(\mathrm{n}=14$, Dec. 26,1984$)$ & 40 \\
\hline Glottidia spp. & 0 & 0 & 1 & 0 & 0 & 0 & 2 & 0 & 1 & 0 & 3 & 1 & 2 & 0 & - & - & - & - & - & - & $(\mathrm{n}=10$, Oct. 10,1984$)$ & 29 \\
\hline Sipunculus nudus & 0 & 1 & 0 & 0 & 1 & 0 & 0 & 0 & 0 & 0 & 0 & 0 & 0 & 0 & - & - & - & - & - & - & $(\mathrm{n}=2$, Jan. 10,1985$)$ & 5.7 \\
\hline \multicolumn{23}{|l|}{ B. 2015} \\
\hline G. audebarti & 0 & 4 & 2 & 0 & 11 & 2 & 3 & 1 & 1 & 1 & 2 & 0 & 0 & 1 & 2 & 0 & 1 & 0 & - & - & $(\mathrm{n}=31$, Dec. 15$)$ & 8.6 \\
\hline G. albida & 2 & 1 & 1 & 0 & 0 & 10 & 15 & 1 & 1 & 0 & 0 & 2 & 1 & 18 & 1 & 0 & 0 & 5 & 6 & 9 & $(\mathrm{n}=73$, Jul. 6$)$ & 18.2 \\
\hline S. nudus & 5 & 11 & 20 & 13 & 3 & 16 & 9 & 13 & 10 & 2 & 11 & 11 & 8 & 7 & 4 & 4 & 13 & 7 & - & - & $(\mathrm{n}=167$, Dec. 15$)$ & 46.4 \\
\hline
\end{tabular}

burrow building sipunculans, brachiopods and enteropneusts. Their burrowing activities and the ingestion-egestion of sediments modify the substrate in such a way, that it becomes suitable or unsuitable for the settlement of larvae or the survival of juveniles of other benthic species (Gray \& Elliott, 2009).

In this study we followed Cutler (1994) and Emig $(1983,1997)$ morphological criteria for the identification of the peanut worms as Sipunculus nudus and Apionsoma trichocephalus, and the lamp shells as Glottidia audebarti and G. albida, respectively. The acorn worms need further taxonomic work and we were reluctant to assign the specimens to categories below Class level.

As its name indicates, G. albida has a white shell while G. audebarti is characterized by the green color on the anterior region of the valves. According to Dall (1921) $G$. albida shells are streaked with brown, but this color pattern was present in only two of the larger specimens found. The type locality of $G$. albida is Magdelena Bay (California, U.S.A.) in $12 \mathrm{~m}$ depth sandy-mud, and for G. audebarti is Guayaquil Bay (Ecuador), in intertidal sand. The presently known distribution of $G$. albida is from California to Costa Rica, while G. audebarti is found from Mexico to Ecuador (Emig, 2009).

The lamp-shells G. auderbarti (Broderip, 1835), and G. albida (Hinds, 1844), are filter feeding lingulide inarticulate brachiopods.
Lingulides live in burrows produced by themselves with the aid of shell movements. Lingulides are euryhaline invertebrates. The organisms retract into the burrows during low tide and emerge with the incoming tide to near sediment surface and filter the water for food. The pedicle end serves as anchor to facilitate vertical movements (Emig, 1997).

The peanut worm $S$. nudus is a sipunculan that has been known to scientists since Linnaeus described this species in 1766 (Hyman, 1959). Specimens collected around the world have morphological features that fit the description of $S$. nudus. Therefore, this species has been considered as cosmopolitan (Cutler, 1994). As such, its potential for use as a worldwide indicator of pollution was advanced by Vargas and Adbullah (1997). The distribution of $S$. nudus as a cosmopolitan species has been questioned based on recent molecular evidence provided by Kawauchi and Giribet (2013) that points to the existence of at least four geographical lineages. However, their study did not include specimens from Costa Rica.

This sipunculan is a prey item for birds foraging at low tide in the Gulf of Nicoya (Pereira, 1996). In China and other Asian countries there is a fishery that exports live $S$. nudus and sells it (market name: BB worm) as fish bait, mainly in Japan (Saito, Kawai, Umino, \& Imabayashi, 2014). The worms are also a food item for human consumption in Asia (SaizSalinas, 1993). 
S. nudus burrows actively in sandy sediments feeding on them as they burrow and has integumentary specializations for gas exchange thru the body surface (Ruppert \& Rice, 1995) facilitating their infaunal mode of life. Sipunculans are able to survive drastic changes in salinity and their lower limit may be around 18 psu (Murina, 1984). Salinities around 20 psu are sometimes found in the upper Gulf of Nicoya estuary during the rainy season (Voorhis, Epifanio, Maurer, Dittel, \& Vargas, 1983).

The acorn worms (Enteropneusta) include about 80 species grouped into several families separated by the structures of the gills, gonads, liver sacs, and coelomic diverticula (Cameron, 2005). The need to observe internal structures in complete specimens makes their proper identification difficult for the non-specialist. In addition, benthic sampling gear (grab, corer) normally yields fragmented specimens of these fragile and usually long organisms. The study by Deland, Cameron, Rao, Ritter, \& Bullock (2010) on the family Harrimaniidae of acorn worms points out that the Eastern Pacific harbors many yet unknown species. In spite of these identification difficulties, information on the presence and abundance of acorn worms is useful for future comparisons of the structure (species diversity and abundance) and functioning (energy flow) of tidal flat systems. In spite of the fact that data from the Punta Morales flat was collected more than three decades ago, it remains as the only study on the ecology of these three groups of invertebrates for this region of the Eastern Tropical Pacific.

Emig \& Vargas (1990) pointed out that the 102 small specimens reported by Vargas (1987) as G. audebarti may include individuals of both species, while the five larger specimens collected the following year were of $G$. audebarti. Thus, abundances of lamp shells for 1984-1987 are reported as Brachiopoda in Fig. 3A. Data collected during 1984-1987 indicates that brachiopods and acorn worms were scarce in cores collected early on 1984 (dry season early rainy season) and increased to a maximum towards the end of 1984 (late rainy - early dry seasons). Sampling started shortly after the end of the period of high temperatures produced by the severe 1982-1983 ENSO. The impact of this warming event on the Peruvian benthos was described by Arntz, Brey, Tarazona, and Robles (1987). In spite of the fact that sampling effort was less after February 1985, numbers of brachiopods and acorn worms were low and patchy from early 1985 to early 1986 , a period when red tides were frequent in the upper Gulf of Nicoya. The impact of these red tides on other infaunal organisms such as the polychaete worms has been discussed by Vargas-Zamora, Sibaja-Cordero, Dean, and Solano-Ulate (2015). Thus, we cannot rule out the possibility that the abundances of brachiopods and acorn worms found early on 1984, and those found during 1985-1986 were in some way also influenced by the end of ENSO and red tides, respectively. In summary, our data provides evidence of the presence of acorn worms in the upper estuary in sand-mud sediments.

The relatively low abundances of $S$. nudus and Glottidia spp. and enteropneusts at the Punta Morales sand mud flat particularly after the red tides of 1985 may indicate that other environmental factors were acting at this time. In this context the 2013 survey data indicates that sediments of the sand-mud flat changed to finer, softer, and higher organic matter content than those found in 1984, perhaps leading to the lack of brachiopods and $S$. nudus in the samples. Brachiopods and S. nudus seem to prefer coarser sediments like those found at Cocorocas in 2015. The enteropneusts appear more tolerant to these changes since numbers near $10 \mathrm{ind} . / 14$ cores were found both in 1984 and 2013. Our data also provides information on the relative importance of these three groups in comparison with other main macro-invertebrates from the Punta Morales flat collected during the 1984-1987 survey, like cephalochordates (Vargas \& Dean, 2010), mollusks (Vargas-Zamora \& Sibaja-Cordero, 2011), echinoderms (Vargas \& Solano, 2011), crustaceans (Vargas-Zamora, Sibaja-Cordero, \& Vargas-Castillo, 2012) and polychaetes (Vargas-Zamora, Sibaja-Cordero, Dean, \& Solano-Ulate, 2015). 
The presence of trace elements in brachiopod shells was reported by Jope (1965) and included $\mathrm{Fe}, \mathrm{Mg}, \mathrm{Mn}$ and $\mathrm{Cu}$. However, data on the composition of shells and tissues of lingulide brachiopods are scarce. Therefore, the reported concentrations of metals in tissues and shells of $G$. audebarti are the first informed for this species. An important observation is that concentrations were different in shells, pedicles, and soft parts indicating different rates of accumulation. Published reports on metal concentrations in other living brachiopods are rare.

The study by De Moreno, Gerpe, Moreno, and Vodopivez (1997) from a pristine site in Antarctica is a notable exception. They found mean concentrations $(\mu \mathrm{g} / \mathrm{g} \mathrm{dw})$ of $\mathrm{Cd}(4.33)$, $\mathrm{Cu}$ (4.87) and $\mathrm{Zn}$ (26.70) in tissues of unidentified brachiopods. As a comparison, mean concentrations $(\mu \mathrm{g} / \mathrm{g} \mathrm{dw})$ of these elements found in soft parts of G. audebarti from the Cocorocas sand flat were: $\mathrm{Cd}$ (5.20), $\mathrm{Cu}$ (12.88) and $\mathrm{Zn}$ (55.20). Thus, concentrations of $\mathrm{Cu}$ and $\mathrm{Zn}$ in $G$. audebarti from the tropical estuarine flat were slightly higher than those from the Antarctic pristine site.

Reports on the evaluation of trace metal concentrations in tissues of sipunculans are also scarce. De Moreno, Gerpe, Moreno and Vodopivez (1997) found in unidentified whole sipunculans from pristine sites in Antarctic mean concentrations $(\mu \mathrm{g} / \mathrm{g} \mathrm{dw})$ of $\mathrm{Cd}(0.47)$, $\mathrm{Cu}$ (14.64) and $\mathrm{Zn}$ (69.9). Mean concentrations $(\mu \mathrm{g} / \mathrm{g} \mathrm{dw})$ of these metals found in whole non-depurated $S$. nudus from the Cocorocas sand flat during the 1996 survey were: $\mathrm{Cd}$ (1.2), $\mathrm{Cu}$ (26) and $\mathrm{Zn}$ (56), and during the 2000 (Table 3) survey the concentrations were: $\mathrm{Cd}$ (0.6), $\mathrm{Cu}$ (20.7) and $\mathrm{Zn}$ (81). Thus, mean concentrations of these three metals in nondepurated Antarctic and tropical sipunculans were of the same orders of magnitude. Yan and Wang (2002) found that sediments are a direct source of metal accumulation in $S$. nudus from a bay in China. They considered that sediment concentrations of less than 0.9 $\mu \mathrm{g} / \mathrm{g}$ of $\mathrm{Cd}$, less than $49 \mu \mathrm{g} / \mathrm{g}$ of $\mathrm{Cr}$, and less than $140 \mu \mathrm{g} / \mathrm{g}$ of $\mathrm{Zn}$ represented a clean site, and maximum concentrations $(\mu \mathrm{g} / \mathrm{g}$ ) were 9.0 for $\mathrm{Cd}, 61.6$ for $\mathrm{Cr}$ and 428 for $\mathrm{Zn}$ at the contaminated sites. For comparison, maximum mean concentrations ( $\mu \mathrm{g} / \mathrm{g} \mathrm{dw}$ ) of $\mathrm{Cd}, \mathrm{Cr}$, and $\mathrm{Zn}$ in the Cocorocas flat sediments (1996 and 2000 surveys) were $1.1,31.5$, and 63, respectively. Thus, the Cocorocas sediments may be considered as relatively clean based on Yan and Wang (2002) criteria. Moreover, Vargas, Acuña González, Gómez, and Molina (2015) concluded that metal concentrations in sediments from the Cocorocas sand flat were those expected for a region of the estuary not as yet impacted by industrial activities. Wang, Yan, and Fan (2002) found that $S$. nudus from the same bay in China retained ingested sediment for about a day and were able to egest unassimilated metals $(\mathrm{Cd}$, $\mathrm{Cr}, \mathrm{Zn}$ ) for up to 72 hours. Thus, the results reported here are in agreement with those found in China in specimens of $S$. nudus as concentrations of metals ( $\mathrm{Fe}, \mathrm{Mn}, \mathrm{Ni}, \mathrm{Zn}, \mathrm{Pb}$ ) in 72 hour depurated $S$. nudus from Cocorocas were lower than those in non-depurated organisms. The fraction of non-assimilated sediments is important enough to influence weight differences between depurated and nondepurated $S$. nudus. Therefore, data on metal concentrations in non-depurated $S$. nudus must be viewed with caution. Ha, Nhuan, Ngoc and Dung (2007) found in non-depurated $S$. nudus from Vietnam mean ppm concentrations $(\mu \mathrm{g} / \mathrm{g}$ $\mathrm{dw}$ ) of: Fe (441), Mn (3.7), Ni (4.7), Zn (21.9), $\mathrm{Pb}$ (5.5), $\mathrm{Cu}$ (1.8), and $\mathrm{Cd}(0.3)$. With the exceptions of $\mathrm{Fe}$, the Vietnamese values were of the same order of magnitude than mean values reported here $(\mu \mathrm{g} / \mathrm{g} \mathrm{dw})$ for $\mathrm{Ni}$ (10.4), $\mathrm{Zn}(81), \mathrm{Pb}(2.8)$ and $\mathrm{Cd}(0.63)$ found in non-depurated $S$. nudus from Cocorocas. Higher concentrations of $\mathrm{Fe}, \mathrm{Mn}$ and $\mathrm{Cu}$ in non-depurated $S$. nudus from Cocorocas, was probably related to their abundance in ingested and unassimilated sediments. Other species of intertidal invertebrates, like certain filter feeding bivalves, are able to lower their metal concentrations after depuration in clean sea water as found by Vargas, Acuña González, Gómez, and Molina (2015) for $\mathrm{Fe}, \mathrm{Mn}, \mathrm{Ni}$, and $\mathrm{Zn}$ in the razor clam Tagelus affinis from the Cocorocas sand flat. Concentrations of $\mathrm{Pb}$ around 
$20 \mu \mathrm{g} / \mathrm{g} \mathrm{dw}$ in sediments, $9.3 \mu \mathrm{g} / \mathrm{g}$ dw in nondepurated $S$. nudus, and $21 \mu \mathrm{g} / \mathrm{g} \mathrm{dw}$ in shells of G. audebarti collected during 1996 may be related to the use of leaded fuel in outboard engines operated by the artisanal fishing fleet at the time; a small fishing village is located at the mouth of the Lagarto River. However, $\mathrm{Pb}$ was found in lower concentrations during the 2000 survey than during 1996. Other metals may have been carried to the sand flat by this river, which drains agricultural lands and brings heavy loads of fine and coarse sediments during the rainy season. Other compounds are also transported by the Lagarto river. For instance, a concentration of $41.4 \mathrm{ng} / \mathrm{g} \mathrm{dw}$ of PCB was found by Spongberg (2006) in S. nudus from Cocorocas. However, this concentration was relatively low when compared with $\mathrm{PCB}$ values found in industrialized estuaries.

Data collected during the 2015 survey confirmed the presence of the brachiopods G. audebarti and G. albida at the Cocorocas sand flat after both species were first collected there by Emig and Vargas (1990). The survey yielded a maximum shell length of $26 \mathrm{~mm}$ for G. albida, and $38 \mathrm{~mm}$ for G. audebarti, which are in agreement with measurements made 25 years ago. Jones and Barnard (1963) conducted a spatial survey of the abundance of G. albida in subtidal coastal sediments of the California $\left(33^{\circ} \mathrm{N}\right)$ coast. This species was more common at depths from $22 \mathrm{~m}$ to $47 \mathrm{~m}$ on a wide variety of sediments. The size distribution of 8976 specimens of G. albida collected by Jones and Barnard (1963) was dominated (86\%) by individuals of less than $5 \mathrm{~mm}$, and only $1 \%$ included individuals of $21-50 \mathrm{~mm}$ long. In tidal flats of the Colorado River mouth $\left(31^{\circ} \mathrm{N}\right)$ in the Gulf of California, small individuals of G. palmeri were rare and this species was found in patches of individuals of mean shell length of about $38 \mathrm{~mm}$ (Kowalewski, 1996).

On the other hand, at Cocorocas individuals smaller than $15 \mathrm{~mm}$ long characterized G. albida. This lingulide almost vanished from the sand flat in December, 2015. In addition, as found by Jones and Barnard (1963), G. albida survives well at its Northern range in non-estuarine coastal waters cooler than $20^{\circ} \mathrm{C}$ and in depths shallower than $60 \mathrm{~m}$. In 1980 a grab survey of 41 subtidal (6 to $65 \mathrm{~m}$ ) stations in the Gulf of Nicoya included 15 stations in the upper estuary. However, as reported by Vargas, Dean, Maurer and Orellana (1985) only one Glottidia sp. specimen was found during the survey (Ballena Bay, $20 \mathrm{~m}$, lower estuary). Estuarine low salinities and higher intertidal temperatures at the Cocorocas sand flat enhanced by the ENSO 2015 (NOAA, 2016) conditions may be among the possible factors preventing this subtidal species to reach a relatively stable presence at the intertidal flat. Moreover, temperatures of $40{ }^{\circ} \mathrm{C}$ and $41{ }^{\circ} \mathrm{C}$ were recorded at noon in tide pools from the Cocorocas sand flat on July 6 and December 15, 2015, respectively.

The presence of $G$. audebarti in the Gulf of Nicoya is at the middle of the latitudinal range of this mainly intertidal species (Emig, 1997) and these two factors may influence its relatively stable presence at Cocorocas. Paine (1963) described the life cycle of G. pyramidata living in intertidal sand bars on the West coast of Florida $\left(29^{\circ} \mathrm{N}\right)$ in salinities ranging from 19 psu to 35 psu. At these sand bars most of G. pyramidata individuals live for about a year with some individuals living up to 20 months. However, comparative information is lacking on the life span of both Glottidia species from the Gulf of Nicoya.

Natural mortality must be important at Cocorocas, although empty shells were never observed. Paine (1963) also points out that the phosphatic shell of Glottidia and its thin organic periostracum decay rapidly in the sediments. Predation on Glottidia spp. by sandpiper shore birds has been observed by Pereira (1996) at nearby sand flats in the Gulf of Nicoya. Naticid snail boreholes are frequently found on molluscan shells at the Punta Morales region (VargasZamora \& Sibaja-Cordero, 2011), but no such boreholes or traces of them have been observed on brachiopod shells from the sites.

At the Cocorocas sand flat maximum mean densities of G. audebarti and G. albida were 8.6 and 18.2 ind. $/ \mathrm{m}^{2}$, respectively. Jones and Barnard (1963) reported densities of 
G. albida of 20 ind. $/ \mathrm{m}^{2}$ in coarser sediments where the onuphid polychate Diopatra sp. was common, while higher densities (up to 500 ind. $/ \mathrm{m}^{2}$ ) coincided with the presence of the ophiuroid Amphioplus hexacanthus. At both the Cocorocas and Punta Morales flats the infaunal ophiuroid, Amphipholis geminata and the onuphid Diopatra ornata are conspicuos elements of the macrofauna (Ditmann \& Vargas, 2001; Vargas \& Solano, 2011). In sand flats from Australia (19 $\left.{ }^{\circ} \mathrm{S}\right) \mathrm{L}$. anatina reached densities of 864 ind. $/ \mathrm{m}^{2}$ (Kenchingtom \& Hammond, 1978), while in intertidal flats in the Gulf of California $\left(31^{\circ} \mathrm{N}\right) \mathrm{G}$. palmeri had densities of up to 300 ind. $/ \mathrm{m}^{2}$ (Kowalewski, 1996). A drastic decline in abundance, from a maximum of $500 \mathrm{ind} . / \mathrm{m}^{2}$ (mean $25-50$ ind. $/ \mathrm{m}^{2}$ ) in 1969 to $0.94 \mathrm{ind} . / \mathrm{m}^{2}$ in 2007 , has been reported for L. reevii in reef flats from Hawaii $\left(21^{\circ} \mathrm{N}\right)$. The decline was related to a decrease in organic matter input and algal mats covering the sediments (Hunter, Krane, \& Fitzpatrick, 2008). At the Bay of Bengal (India, $14^{\circ} \mathrm{N}$ ) L. translucida reached densities between 4 ind. $/ \mathrm{m}^{2}$ and 92 ind. $/ \mathrm{m}^{2}$ (mean 46 ind. $/ \mathrm{m}^{2}$ ) estimated from $0.25 \mathrm{~m}^{2}$ quadrats collected along three transects on an intertidal beach under the influence of a brackish water river (Raughnathan \& Jothinayagam, 2007). Thus, densities of both G. audebarti and G. albida at Cocorocas appear relatively modest when compared with data from higher latitudes, but similar to those of G. translucida found in a tropical habitat in India under the influence of a river.

The 2015 sampling at the Cocorocas sand flat also confirmed the presence of the sipunculan $S$. nudus. Individuals representing nine weight groups of this peanut worm were found, but with most of the individuals were in the 0.1 to $1.0 \mathrm{~g}$ range. Representatives of this range increased in abundance from July to December indicating possible growth of the individuals. Both new (lighter) and heavier (probably older) specimens were present during the sampling period, which may represent a relatively stable population. A density of 5 ind. $/ \mathrm{m}^{2}$ of $S$. nudus is mentioned by Saiz-Salinas (1993). Therefore, densities of about $34.5 \mathrm{ind} . / \mathrm{m}^{2}$ found at the Cococorcas sand flat are relatively high.
However, their mean size of $45 \mathrm{~mm}$ is relatively small if the maximum size $(340 \mathrm{~mm})$ also cited by Saiz-Salinas (1993) and a photograph in Ha, Nhuan, Ngoc, and Dung (2007) are considered for comparison. These latter authors indicate that $S$. nudus is more abundant in sand flats from Vietnam where sediments contain more than $80 \%$ sand, and is rarely found if the sand content is less than $60 \%$. These values may explain the relatively high abundance of S. nudus in Cocorocas sediments (90\% sand) when compared to their low abundance in the $65 \%$ sand content of the Punta Morales flat.

The distribution of individuals in space is a fundamental characteristic of soft-bottom species (Thrush, 1991). G. palmeri and other lingulides occur in patches in the intertidal zone (Kowalewski, 1996). Our data indicates that spatial patchiness characterizes the abundance of the three species at the Cocorocas sand flat. The two brachiopods and S. nudus were frequently found together within a single quadrat area, as illustrated for G. audebarti and $S$. nudus for the 18 quadrats collected on Dec. 15, 2015. The number of individuals collected in a single quadrat ranged from 0 to 11 (G. audebarti), 0 to 18 (G. albida) and 0 to 20 ( $S$. nudus), which may indicate subtle differences in sediment grain size and other factors (like presence of adults) attractive or dissuasive for site selection by settling larvae and later survival of juveniles (Gray \& Elliot, 2009).

Spatial and temporal patchiness is also important in the context of fishing potential of certain species since relatively high mean densities at a given sediment spot or time may be misleading. The sipunculan $S$. nudus is not as yet exploited commercially in Costa Rica, but it has been used as fish bait for generations. The peanut worm coexists at Cocorocas with the lamp shells and the small razor clam T. affinis which is already under moderate fishing pressure.

Brachiopods of the genus Lingula are harvested commercially in Southeast Asia (Brusca, Moore, \& Shuster, 2016). Future exploitation of populations of lamp shells in the Gulf of Nicoya may be expected, and management 
policies are urgently needed to prevent future overfishing of these species. Other tidal flat species from the Gulf of Nicoya, like Anadara spp. ark clams (Stern-Pirlot \& Wolff, 2006) and the giant polychaete Americonuphis reesei (Rojas \& Vargas, 2008) are examples of living resources where management strategies have been implemented with relatively good results in this tropical estuary.

\section{ACKNOWLEDGMENTS}

We thank Davis Morera and Eleazar Ruiz for their help in the field collections during 2000, 2013 and 2015. Eddy Gómez and Johan Molina helped with the chemical laboratory work. We thank three anonymous reviewers for comments on the manuscript. Data collected during 1984-1987 was part of the Ph. D. Dissertation by the senior author at the University of Rhode Island, U.S.A. We thank the late John S. Gray for supporting the 1996 trace metal analysis at the University of Oslo, Norway. Trace metal anaylsis during 2000 were made possible by a grant from the Costa Rica-United States of America Foundation (CR-USA) to the senior author (Project VI-808-A0-506 Coastal pollution in Costa Rica). This paper was prepared as part of projects VI-808-B3-113 The benthos of Punta Morales-30 years later, and VI-808-B3-127 Microbial ecology and marine biogeochemistry of the Gulf of Nicoya, funded by research grants from the University of Costa Rica.

\section{RESUMEN}

Braquiópodos, sipuncúlidos, enteropneustos y metales en dos planicies estuarinas de marea, Pacífico, Costa Rica. Son raros los reportes sobre las abundancias y concentraciones de metales en invertebrados estuarinos de la zona de entre-mareas del Pacífico Este Tropical. Los objetivos de este informe son el hacer accesibles datos sobre las abundancias (1984-1987, 49 fechas; 2013, 12 fechas) de sipuncúlidos, braquiópodos y hemicordados en una planicie arenoso-fangosa y sobre metales traza $(1996,2000)$ y abundancias (2015, 3 fechas) de sipuncúlidos y braquiópodos en una planicie arenosa en el estuario del Golfo de Nicoya $\left(10^{\circ} \mathrm{N}-85^{\circ} \mathrm{W}\right)$. Barrenos $\left(17.7 \mathrm{~cm}^{2}\right)$ fueron recolectados en la planicie arenoso-fangosa y cuadrantes $\left(0.2 \mathrm{~m}^{2}\right)$ en la arenosa. Las planicies contrastaron en sus contenidos de arena $(65 \%$ vs $90 \%)$ y de limo + arcilla $(31.5 \%$ vs $5.6 \%)$. En la planicie arenoso-fangosa (1984-87: $1.83 \mathrm{~m}^{2}$ ) los sipuncúlidos estuvieron representados por 13 individuos, los braquiópodos por 129 y los hemicordados enteropneustos por 185 , con densidades estimadas de: 5.7, 29, y 40 ind. $/ \mathrm{m}^{2}$, respectivamente. Análisis de metales traza (Fe, Mn, Ni, Cr, $\mathrm{Cd}, \mathrm{Zn}, \mathrm{y} \mathrm{Pb}$ ) por Espectrometría de Absorción Atómica (AAS) fueron hechos en especímenes de Sipunculus nudus (Sipuncula) y Glottidia audebarti (Brachiopoda). Concentraciones máximas promedio en $S$. nudus fueron: para gusanos no-depurados, Fe $(16.0 \mathrm{mg} / \mathrm{g} \mathrm{dw})>\mathrm{Mn}(165 \mu \mathrm{g} / \mathrm{g}$ $\mathrm{dw})>\mathrm{Zn}(81 \mu \mathrm{g} / \mathrm{g} \mathrm{dw})>\mathrm{Cu}(26 \mu \mathrm{g} / \mathrm{g} \mathrm{dw})>\mathrm{Cr}(11 \mu \mathrm{g} / \mathrm{g}$ $\mathrm{dw})>\mathrm{Ni}(10.4 \mu \mathrm{g} / \mathrm{g} \mathrm{dw})>\mathrm{Pb}(9.3 \mu \mathrm{g} / \mathrm{g} \mathrm{dw})>\mathrm{Cd}(1.2 \mu \mathrm{g} / \mathrm{g}$ $\mathrm{dw})$. Para gusanos depurados por 72 horas: Fe $(5.0 \mathrm{mg} / \mathrm{g}$ $\mathrm{dw})>\mathrm{Mn}(61 \mu \mathrm{g} / \mathrm{g} \mathrm{dw})>\mathrm{Zn}(39 \mu \mathrm{g} / \mathrm{g} \mathrm{dw})>\mathrm{Cu}(24 \mu \mathrm{g} / \mathrm{g}$ $\mathrm{dw})>\mathrm{Ni}(8.4 \mu \mathrm{g} / \mathrm{g} \mathrm{dw})>\mathrm{Pb}(2.7 \mu \mathrm{g} / \mathrm{g} \mathrm{dw})>\mathrm{Cd}(0.62 \mu \mathrm{g} / \mathrm{g}$ $\mathrm{dw})$. Para G. audebarti: Fe (1.6 mg/g dw-partes suaves) $>\mathrm{Zn}(123.5 \mu \mathrm{g} / \mathrm{g}$ dw-partes suaves $)>\mathrm{Cu}(31.4 \mu \mathrm{g} / \mathrm{g} \mathrm{dw}-$ pedículos $)>\mathrm{Pb}(21.0 \mu \mathrm{g} / \mathrm{g}$ dw-conchas $)>\mathrm{Cd}(5.2 \mu \mathrm{g} / \mathrm{g}$ dw-partes suaves $)>\mathrm{Cr}(4.7 \mu \mathrm{g} / \mathrm{g} \mathrm{dw}$-conchas $)$. Para sedimentos; Fe (46 mg/g dw) > Mn $(41.3 \mu \mathrm{g} / \mathrm{g} \mathrm{dw})>\mathrm{Zn}(63$ $\mu \mathrm{g} / \mathrm{g} \mathrm{dw})>\mathrm{Cu}(36.2 \mu \mathrm{g} / \mathrm{g} \mathrm{dw})>\mathrm{Cr}(31.5 \mu \mathrm{g} / \mathrm{g} \mathrm{dw})>\mathrm{Pb}$ $(21.1 \mu \mathrm{g} / \mathrm{g} \mathrm{dw})>\mathrm{Ni}(16.1 \mu \mathrm{g} / \mathrm{g} \mathrm{dw})>\mathrm{Cd}(1.1 \mu \mathrm{g} / \mathrm{g} \mathrm{dw})$. Estas concentraciones fueron esperables para un estuario no industrializado. En la planicie arenosa (Area muestreada: $\left.10.6 \mathrm{~m}^{2}\right) 76$ individuos de G. audebarti, 112 de G. albida y 366 de $S$. nudus fueron recolectados en el 2015, con densidades estimadas de: $7.1,10.5$, y 31 ind. $/ \mathrm{m}^{2}$, respectivamente. Densidades de G. audebarti y G. albida fueron relativamente bajas, mientras que las de $S$. nudus fueron relativamente altas cuando se les comparó con otros reportes. La longitud de la concha de G. audebarti varió entre $9.0 \mathrm{~mm}$ y $38.0 \mathrm{~mm}$ y entre $6.0 \mathrm{~mm}$ a $29.0 \mathrm{~mm}$ la de G. albida. Estos ámbitos estuvieron dentro de los encontrados para estos lingúlidos en otros sitios. La longitud promedio de $S$. nudus fue $41 \mathrm{~mm}$ y el peso máximo fue de $1.6 \mathrm{~g}$ que son pequeños. En la planicie arenoso-fangosa no se encontró braquiópodos en el 2013, ni enteropneustos en la planicie arenosa en el 2015. $G$. audebarti tuvo una presencia relativamente estable, mientras que G. albida casi desapareció de las muestras al final del 2015. La distribución espacial de las tres especies fue de tipo agregado en ambas planicies. Fuertes eventos ENSO durante 1983 y 2015, así como mareas rojas en 1985, pueden haber influenciado las abundancias.

Palabras clave: Glottidia, Sipunculus, Apionsoma, gusanos bellota, bentos tropical, infauna, contaminación, depuración.

\section{REFERENCES}

Acuña-González, J. A., Vargas-Zamora, J. A., GómezRamírez, E., \& García-Céspedes, J. (2004). Hidrocarburos de petróleo, disueltos y dispersos, en cuatro ambientes costeros de Costa Rica. Revista de Biología Tropical, 52 (Suppl. 2), 43-50. 
Arntz, W., Brey, E., Tarazona, J., \& Robles, A. (1987) Changes in the structure of a shallow sandy beach community in Peru during an El Niño event. South African Journal of Marine Science, 5, 645-658.

Borja, A., Dauer, D. M., \& Elliott, M. (2010). Medium and long-term recovery of estuarine and coastal ecosystems: Patterns, rates, and restoration effectiveness. Estuaries and Coasts, 33, 1245-1260.

Brusca, R. C., Moore, W., \& Shuster, S. M. (2016). Invertebrates. $3^{\text {rd }}$ edition. Sunderland, MA, USA.: Sinauer Associates Inc.

Cameron, C. B. (2005). A phylogeny of the hemichordates based on morphological characters. Canadian Journal of Zoology, 83, 196-215.

Cloern, J. E., Foster, S. Q., \& Kleckner, E. (2014). Phytoplankton primary production in the world's estuarinecoastal ecosystems. Biogeosciences, 11, 2477-2501.

Cutler, N., Cutler, E., \& Vargas, J. A. (1992). Peanut worms (Phylum Sipuncula) from Costa Rica. Revista de Biologia Tropical,40, 153-158.

Cutler, E. B. (1994). The Sipuncula: Their systematics, biology, and evolution. Ithaca, New York, U.S.A: Comstock Publishing Association.

Dall, W. H. (1921). Annotated list of Recent Brachiopoda in the collections of the United States National Museum, with descriptions of thirty-three new forms. Proceedings of the U. S. National Museum, 57, 261-377.

Deland, C., Cameron, C. B., Rao, K. P., \& Bullock, T. H. (2010). A taxonomic revision of the family Harrimaniidae (Hemichordata: Enteropneusta) with description of seven species from the Eastern Pacific. Zootaxa, 2408, 1-30.

De Moreno, J. E. A., Gerpe, M. S., Moreno, V. S., \& Vodopivez, C. (1997). Heavy metals in Antartic organisms. Polar Biology, 17, 131-140.

Dittmann, S., \& Vargas, J. A. (2001). Tropical tidal flat benthos compared between Australia and Central America. In K. Reise (Ed.), Ecological Comparisons of Sedimentary Shores (pp. 275-293). Vol. 151, Ecological Studies. Berlin, Germany: Springer.

Dittmann, S. (2002). Benthic fauna in tropical tidal flats - a comparative perspective. Wetlands Ecology and Management, 10, 189-195.

Emig, C. C., \& Vargas, J. A. (1990). Glottidia audebarti (Broderip) (Brachiopoda, Lingulidae) from the Gulf of Nicoya, Costa Rica. Revista de Biología Tropical, $38,251-258$

Emig, C. C. (1983). Taxonomie du genre Glottidia (Brachiopodes, Inarticulés). Bulletin du Muséum National d'Histoire Naturelle, Paris. $4^{\mathrm{e}}$ Ser. 5. Section A. $\mathrm{n}^{\mathrm{o}}$. 2, 469-489.
Emig, C. C. (1997). Ecology of inarticulate brachiopods. In R. L. Kaesler (Ed.), Treatise on Invertebrate Paleontology, Part H. Brachiopoda revised (pp. 473-495). Boulder, Colorado \& Laurence, Kansas. U.S.A.: Geological Society of America and University of Kansas.

Emig, C. C. (2009). Brachiopods. Text: pp. 417-420. Species list: CD pp. 119-121. In I. S. Wehrtmann \& J. Cortés (Eds.). Marine Biodiversity of Costa Rica, Central America. Monogr. Biol. 86. Berlín: Springer + Business Media B.V.

García-Céspedes, J., Acuña-González, J., \& Vargas-Zamora, J. A. (2004). Metales traza en sedimentos costeros de Costa Rica. Revista de Biología Tropical, 52 (Supl. 2), 51-60.

García, V., J., Acuña-González, J., Vargas-Zamora, J. A., \& García-Céspedes, J. (2006). Calidad bacteriológica y desechos sólidos en ambientes costeros de Costa Rica. Revista de Biología Tropical, 54 (Supl. 1), 35-48.

Gray, J. S., \& Elliott, M. (2009). Ecology of Marine Sediments- from science to management. $2^{\text {nd }}$ ed. Oxford, U.K.: Oxford University Press.

Gravel, P., Johanning, K., McLachlan, J., Vargas, J. A., \& Oberdorster, E. (2006). Imposex in the intertidal snail Thais brevidentata (Gastropoda-Muricidae) from the Pacific coast of Costa Rica. Revista de Biología Tropical, 54 (Suppl. 1), 21-26.

Ha, N. T. T., Nhuan, M. T., Ngoc, N. T., \& Dung, H. T. (2007). The distribution of peanut-worm (Sipunculus nudus) in relation to geo-environmental characteristics. VNU Journal of Sciences, Earth Sciences, 23, 110-115.

Hunter, C. L., Krane, E., \& Fitzpatrick, J. (2008). Current and historic distribution and abundance of the inarticulate brachiopod, Lingula reevii Davidson (1880) in Kaneohe Bay, Oahu, Hawaii, U.S.A. Marine Biology, $155,205-210$

Hyman, L. H. (1959). The Invertebrates. Vol. V: Smaller Coelomate Groups - Chaetognatha, Hemichordata, Pogonophora, Phoronida, Ectoprocta, Brachiopo$d a$, Sipunculida. The coelomate bilateria. New York, U.S.A.: McGraw-Hill Book Company Inc.

Jones, G. F., \& Barnard, J. L. (1963). The distribution and abundance of the inarticulate btachiopod Glottidia albida (Hinds) on the mainland shelf of Southern California. Pacific Naturalist, 4, 27-52.

Jope, H. M. (1965). Composition of the brachiopod shell. In R. C. Moore (Ed.), Treatise on Invertebrate Paleontology, Vol. I. Part. H. Brachiopoda (pp. 156164). Kansas, U.S.A.: The Geological Society of America-The University of Kansas Press.

Kawauchi, G. Y., \& Giribet, G. (2013). Sipunculus nudus Linnaeus, 1766 (Sipuncula): cosmopolitan or a group of pseudo-cryptic species? Marine Ecology, 2013, 1-14. 
Kenchington, R. A., \& Hammond, L. S. (1978). Population structure, growth and distribution of Lingula anatina (Brachiopoda) in Queensland, Australia. Journal of Zoology, London, 184, 63-81.

Kowalewski, M. (1996). Taphonomy of a living fossil: The lingulide brachiopod Glottidia palmeri Dall from Baja California, Mexico. Palaios, 11: 244-265.

Kowalewski, M., Dyreson, E., Marcot, J. D., Vargas, J. A., Flessa, K. W., \& Hallman, D. P. (1997). Phenetic discrimination of biometric simpletons: paleobiological implications of morphospecies in the lingulide brachiopod Glottidia. Paleobiology, 23, 444-469.

Lecuyer, C., Grandjean, P., \& Emig, C. C. (1996). Determination of oxygen isotope fractions between water and phosphate from living lingulids: potential applications to paleoenvironmental studies. Paleogeography, Paleoclimatology, Paleoecology, 121, 101-108.

Murina, G. V. (1984). Ecology of Sipuncula. Marine Ecology Progress Series, 17, 1-7.

NOAA-National Oceanographic \& Atmospheric Administration. (2016). El Niño-Southern Oscillation (ENSO) Diagnostic Discussion. Jan. 14, 2016. College Park, Maryland, U.S.A.: National Weather Service. National Center for Environmental Prediction-Climate Prediction Center.

Paine, R. T. (1963). Ecology of the brachiopod Glottidia pyramidata. Ecological Monographs, 33, 187-213.

Pereira, A. I. (1996). The impact of foraging by sandpipers (Scolopacidae) on populations of invertebrates in the intertidal zone of Chomes beach, Gulf of Nicoya, Costa Rica. In P. Hicklin (Ed.). Shorebird ecology and conservation in the Western Hemisphere (pp. 44-51). Canada: International Wader Studies 8.

Raughnathan, C., \& Jothinayagam, J. T. (2007). Occurrence of 'living fossil' Lingula translucida Dahl (Brachiopoda, Lingulidae) along Krishnapatnam coast of Bay of Bengal. Seshaiyana, 15, 3-6.

Rojas, R., \& Vargas, J. A. (2008). Abundancia, biomasa y relaciones sedimentarias de Americonuphis reesei (Polychaeta: Onuphidae) en el Golfo de Nicoya, Costa Rica. Revista de Biología Tropical, 56 (Supl. 4), 59-82.

Ruppert, E. E. \& Rice, M. E. (1995). Functional organization of dermal coelomic canals in Sipunculus nudus (Sipuncula) with a description of respiratory designs in sipunculans. Invertebrate Biology, 114, 51-63.

Saito, H., Kawai, K., Umino, T., \& Imabayashi, H. (2014). Fishing bait worm supplies in Japan in relation to their physiological traits. Memoirs of Museum Victoria, 71, 279-287.
Saiz-Salinas, J. I. (1993). Sipuncula. Fauna Ibérica. Vol. 4. Madrid, España: Museo Nacional de Ciencias Naturales - Consejo Superior de Investigaciones Científicas.

Spongberg, A. L. (2004). PCB concentrations in sediments from the Gulf of Nicoya estuary, Pacific coast of Costa Rica. Revista de Biología Tropical, 52, (Suppl. 2), 11-22.

Spongberg, A. L. (2006). PCB concentrations in intertidal sipunculans (Phylum Sipuncula) from the Pacific of Costa Rica. Revista de Biología Tropical, 54, (Suppl. 1), 27-33.

Spongberg, A. L., Witter, J. D., Acuña, J., Vargas, J. A., Murillo, M., Umaña, G., Gómez, E., \& Perez, G. (2011). Reconnaissance of selected P.P.C.P. compounds in Costa Rican surface waters. Water Research, 45, 6709-6717.

Stern-Pirlot, A., \& Wolff, M. (2006). Population dynamics and fisheries potencial of Anadara tuberculosa (Bivalvia: Arcidae) along the Pacific coast of Costa Rica. Revista de Biología Tropical, 54 (Suppl. 1), 87-99.

Thrush, S. F. (1991). Spatial patterns in soft-bottom communities. Trends in Ecology and Evolution, 6, 75-79.

Vargas, J. A., Dean, H. K., Maurer, D., \& Orellana, P. (1985). Lista preliminar de invertebrados asociados a los sedimentos del Golfo de Nicoya, Costa Rica. Brenesia, 24, 327-342.

Vargas, J. A. (1987). The benthic community of an intertidal mud flat in the Gulf of Nicoya, Costa Rica. Description of the community. Revista de Biología Tropical, 35, 229-316.

Vargas, J. A. (1988). Community structure of macrobenthos and the results of macropredator exclusion on a tropical mud flat. Revista de Biología Tropical, 36, 287-308.

Vargas, J. A. (1989). A three year survey of the macrofauna of an intertidal mud flat in the Gulf of Nicoya, Costa Rica. In O. Magoon, M. Converse, D. Miner, L.T. Tobin and D. Clark (Eds.), New York: American Society of Civil Engineers, Proceedings $6^{\text {th }}$ Symposium on Coastal and Ocean Management, Vol. 2, 1905-1919.

Vargas, J. A. (1995). The Gulf of Nicoya estuary, Costa Rica. Past, present, and future cooperative research. Helgoländer Meeresunters, 49, 821-828.

Vargas, J. A. (1996). Ecological dynamics of a tropical intertidal mudflat community. In K. F. Nordstrom and C. T. Roman (Eds.), Estuarine Shores: Evolution, Environments and Human Alterations (pp. 355-371). London: John Wiley \& Sons Ltd.

Vargas, J. A., \& Abdullah, M. (1997). Trace metals in Sipunculus nudus (Sipuncula) and Glottidia audebarti (Brachiopoda) from a tropical estuarine sand flat. pp. 76. In Abstracts. Melbourne, FL. USA: Third 
International Ocean Pollution Symposium (3IOPS) - Pollutants in Marine Organisms. Harbor Branch Oceanographic Institution. - Environmental Information Systems, Inc.

Vargas, J. A., \& Dean, H. K. (2009). Sipunculans. Text: pp. 175-180, Species list: CD. pp. 119-121. In I. S. Wehrtmann and J. Cortés (Eds.). Marine Biodiversity of Costa Rica, Central America. Monogr. Biol. 86. Berlín: Springer + Business Media B.V.

Vargas, J. A., \& Dean, H. K. (2010). On Brachiostoma californiense (Cephalochordata) from the Gulf of Nicoya estuary, Costa Rica. Revista de Biología Tropical, 58, 1143-1148.

Vargas, J. A., \& Solano, S. (2011). On Mellitella stokesii and Amphipholis geminata (Echinodermata), from an intertidal flat in the upper Gulf of Nicoya estuary, Pacific, Costa Rica. Revista de Biología Tropical, 59, 193-198.

Vargas, J. A., Acuña-González, J., Gómez, E., \& Molina, J. (2015). Metals in coastal mollusks of Costa Rica. Revista de Biología Tropical, 63, 1007-1019.

Vargas, J. A. (2016). The Gulf of Nicoya estuarine ecosystem. In M. Kaapelle (Ed.), Ecosystems of Costa Rica (pp. 106-124). Chicago, U.S.A.: University of Chicago Press.
Vargas-Zamora, J. A., \& Sibaja-Cordero, J. A. (2011). A Molluscan assemblage from a tropical intertidal estuarine sand-mud flat, Gulf of Nicoya, Pacific, Costa Rica (1984-1987). Revista de Biología Tropical, 59, 1135-1148.

Vargas-Zamora, J. A., Sibaja-Cordero, J. A., \& VargasCastillo, R. (2012). Crustaceans from a tropical estuarine sand-mud flat, Pacific, Costa Rica, (1984-1988) revisited. Revista de Biología Tropical, 60, 1763-1781.

Vargas-Zamora, J. A., Sibaja-Cordero, J. A., Dean, H. K., \& Solano-Ulate, S. (2015). Abundance patterns (19841987/1994-1998) of polychaete worms (Annelida) from an estuarine tidal flat, Pacific, Costa Rica. Cuadernos de Investigación UNED, 7, 233-247.

Voorhis, A., Epifanio, C. E., Maurer, D., Dittel, A. I., \& Vargas, J. A. (1983). The estuarine character of the Gulf of Nicoya, an embayment on the Pacific coast of Central America. Hydrobiologia, 99, 225-237.

Yan, Q. L., \& Wang, W. X. (2002). Metal exposure and bioavailability to a marine deposit-feeding Sipuncula, Sipunculus nudus. Environmental Science \& Techno$\log y, 36,40-47$.

Wang, W. X., Yan, Q. L., \& Fan, W. (2002). Bioavailability of sedimentary metals from a contaminated bay. Marine Ecology Progress Series, 240, 27-38. 
